\title{
Lithium Di- and Trimethyl Dimolybdenum(II) Complexes with Mo-Mo Quadruple Bonds and Bridging Methyl Groups
}

\author{
Natalia Curado, Mario Carrasco, Eleuterio Álvarez, Celia Maya, Riccardo Peloso, Amor \\ Rodríguez, Joaquín López-Serrano, ${ }^{*}$ and Ernesto Carmona*
}

Instituto de Investigaciones Químicas (IIQ), Departamento de Química Inorgánica and Centro de Innovación en Química Avanzada (ORFEO-CINQA). Universidad de Sevilla and Consejo Superior de Investigaciones Científicas (CSIC). Avenida Américo Vespucio, 49, 41092 Sevilla, Spain

KEYWORDS. Bridging methyl groups $\bullet$ multiple bonds $\bullet$ molybdenum $・$ NMR spectroscopy $\cdot$ computational studies.

\begin{abstract}
New dimolybdenum complexes of composition $\left.\left[\mathrm{Mo}_{2}\{\mu-\mathrm{Me}\}_{2} \mathrm{Li}(\mathrm{S})\right\}(\mu-\mathrm{X})\left(\mu-\mathrm{N}^{\wedge} \mathrm{N}\right)_{2}\right]\left(\mathbf{3}^{\mathrm{a}-3 \mathbf{c}}\right)$ where $\mathrm{S}=\mathrm{THF}$ or $\mathrm{Et}_{2} \mathrm{O}$ and $\mathrm{N}^{\wedge} \mathrm{N}$ represents a bidentate aminopyridinate or amidinate ligand that bridges the quadruply bonded molybdenum atoms, were prepared from the reaction of the appropriate $\left[\mathrm{Mo}_{2}\left\{\mu-\mathrm{O}_{2} \mathrm{CMe}\right\}_{2}\left(\mu-\mathrm{N}^{\wedge} \mathrm{N}\right)_{2}\right]$ precursors and LiMe. For complex 3a, $\mathrm{X}=\mathrm{MeCO}_{2}$, while in $\mathbf{3} \mathbf{b}$ and $\mathbf{3} \mathbf{c}, \mathrm{X}=$ Me. Solution NMR studies in $\mathrm{C}_{6} \mathrm{D}_{6}$ solvent support formulation of the complexes as contact ion pairs with weak agostic $\mathrm{Mo}-\mathrm{CH}_{3} \cdots \mathrm{Li}$ interactions, that were also evidenced by $\mathrm{X}$-ray crystallography in the solid-state structures of the molecules of $\mathbf{3 a}$ and $\mathbf{3} \mathbf{b}$. Samples of $\mathbf{3} \mathbf{c}$ enriched in ${ }^{13} \mathrm{C}(99 \%)$ at the metal-bonded methyl sites were also prepared and investigated by NMR spectroscopy employing $\mathrm{C}_{6} \mathrm{D}_{6}$ and THF- $d_{8}$ solvents. Crystallization of 3c from toluene:tetrahydrofuran mixtures provided single crystals of the solvent separated ion pair complex $\left[\mathrm{Li}(\mathrm{THF})_{4}\right]\left[\mathrm{Mo}_{2}(\mathrm{Me})_{2}(\mu-\mathrm{Me})\left\{\mu-\mathrm{HC}(\mathrm{NDipp})_{2}\right\}_{2}\right](4 \mathrm{c})$, where Dipp stands for $2,6-i \mathrm{Pr}_{2} \mathrm{C}_{6} \mathrm{H}_{3}$. A computational analysis of the $\mathrm{Mo}_{2}(\mu-\mathrm{Me})_{2} \mathrm{Li}$ core of complexes $3 \mathbf{a}$ and $\mathbf{3} \mathbf{b}$ has been developed which is consistent with a small but non-negligible electron-density sharing between the $\mathrm{C}$ and $\mathrm{Li}$ atoms of the mainly ionic $\mathrm{CH}_{3} \cdots \mathrm{Li}$ interactions.
\end{abstract}

\section{INTRODUCTION}

Transition metal alkyl and aryl complexes form a most representative family of metal organic compounds. ${ }^{1,2}$ The unique reactivity of the $\sigma \mathrm{M}-\mathrm{C}$ bond allows for its participation in elementary reactions which are the basis of many academic and industrial transformations. In addition, they have furnished unusual molecular and electronic structures, ${ }^{3}$ including the synthesis by Wilkinson and co-workers of $\mathrm{WMe}_{6},{ }^{4}$ the first hexamethyl transition metal compound, and the recent discovery by the group of Power of the first stable molecule with quintuple metal-metal bonding, the chromium dimer $\mathrm{Cr}_{2} \mathrm{Ar}^{\prime}{ }_{2}$, where $\mathrm{Ar}^{\prime}$ represents a terphenyl ligand. ${ }^{5}$

The methyl group is the simplest alkyl function and occupies a conspicuous position among metal alkyls. Leaving aside the fundamental and practical importance of main group methyl compounds, e.g. LiMe, $\operatorname{Mg}(\mathrm{Me}) \mathrm{X}$, $\mathrm{ZnMe}_{2}$ or $\mathrm{AlMe}_{3}{ }^{1 \mathrm{~d}, \mathrm{2b}}$ transition metal methyl complexes are arguably the most important family of compounds with $\mathrm{M}-\mathrm{C} \sigma$ bonds. $^{6}$ Moreover, some members of this group have provided the grounds for major breakthroughs in organometallic chemistry such as the isolation of the first methylidene complex ${ }^{7}$ or the low temperature NMR characterization of the first $\sigma-\mathrm{CH}_{4}$ complex. ${ }^{8}$

Recent activity in the field of binuclear transition metal compounds that feature metal-metal multiple bonds, sparked by the already cited synthesis of $\mathrm{Cr}_{2} \mathrm{Ar}_{2}{ }_{2}$ compounds, led us to study the utility of the well-known precursor $\left[\mathrm{Mo}_{2}\left(\mathrm{O}_{2} \mathrm{CMe}\right)_{4}\right]^{9}$ for the synthesis of Mo-Mo quadruple bonds. ${ }^{10}$ With the use of bridging aminopyridinate $^{10,11}$ and amidinate ${ }^{10,12,13}$ ligands that possess bulky aryl substituents, we have recently prepared some multiply bonded dimolybdenum species. ${ }^{14,15}$ Combining the alluring prospects of this area of research ${ }^{10-20}$ with the enticements of the study of $\mathrm{M}-\mathrm{C} \sigma$ bonds, we have investigated a series of methyl complexes of the Mo $\equiv$ Mo core, stabilized by coordination of the aminopyridinate and amidinate ligands (1a-1c) represented in Figure 1 . The new compounds comprise some lithium di- and trimethyl dimolybdenum(II) ate complexes (3a-3c and 4c) that are the subject of this paper.

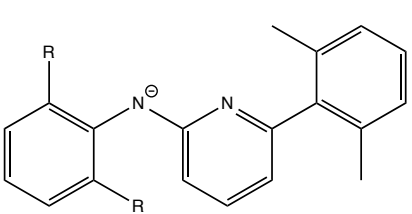

R: $i \operatorname{Pr}, \mathbf{1 a} ; \mathrm{Me}, \mathbf{1 b}$

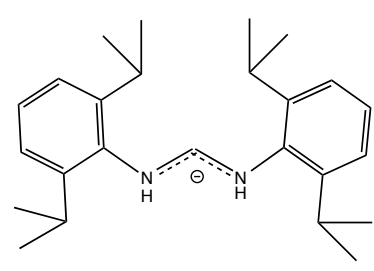

1c
Figure 1. The aryl-substituted aminopyridinate (left) and amidinate (right) ligands employed in this work. Throughout this paper, labels $\mathbf{a}, \mathbf{b}$, and $\mathbf{c}$ in the numbering scheme refer 
specifically to the above ligands (some authors prefer the term pyridylamido to design ligands of type $\mathbf{1 a}$ and $\mathbf{1 b}$ ).

As discussed next, the new complexes $3 \mathbf{a}-\mathbf{3} \mathbf{c}$ and $4 \mathbf{c}$ feature coordinated methyl groups with three different binding modes, namely terminal Mo-Me, bridging $\mathrm{Mo}(\mu-$ $\mathrm{Me}) \mathrm{Mo}$ and bridging $\mathrm{Mo}(\mu-\mathrm{Me}) \mathrm{Li}$ units (Figure 2). Moreover they contain an uncommon $\mathrm{Li}(\mu-\mathrm{Me}) \mathrm{Mo} \equiv \mathrm{\equiv} \equiv(\mu-\mathrm{Me})$ structural motif that finds no precedent among the compounds listed in the Cambridge Structural Database (CSD) ${ }^{21} \mathrm{X}$-ray crystallography (complexes $3 \mathbf{a}$ and $\mathbf{3} \mathbf{b}$ ) and multinuclear NMR studies $\left(\mathrm{C}_{6} \mathrm{D}_{6}\right.$ solvent) have unequivocally demonstrated its existence in the molecules of $3^{3}$ 3b. Samples of $\mathbf{3 c}$ could not be isolated in the form of single-crystals as crystallization from 1:1 mixtures of toluene and THF yielded instead the related, albeit solvent separated ion pair complex $\left[\mathrm{Li}(\mathrm{THF})_{4}\right]\left[\mathrm{Mo}_{2} \mathrm{Me}_{3}\left(\mathrm{~N}^{\wedge} \mathrm{N}\right)_{2}\right]$ (4c) featuring two terminal Mo-Me bonds and a bridging $\mathrm{Mo}(\mu-\mathrm{Me})$ Mo linkage (Figure 2).

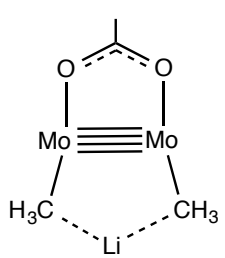

(S)

3a

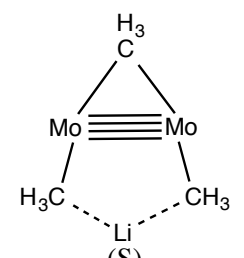

(S)

3b, $3 \mathbf{c}$

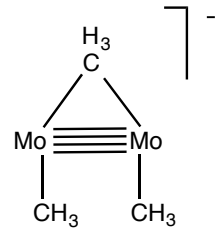

$4 c$
Figure 2. Simplified structural representations of the organometallic $\mathrm{Mo}_{2}$ core of complexes $3 \mathbf{a}-3 \mathbf{c}$ and $4 \mathbf{c}$. The bridging aminopyridinate and amidinate ligands have been omitted for clarity. S represents a lithium coordinated molecule of $\mathrm{Et}_{2} \mathrm{O}$ or THF (see text).

\section{RESULTS AND DISCUSSION}

The polymethyl dimolybdenum(II) complexes $\mathbf{3 a - 3 \mathbf { c }}$ described in this work were prepared from the corresponding bis(acetate) precursors with paddlewheel structures $\left.\left[\mathrm{Mo}_{2}\left(\mathrm{O}_{2} \mathrm{CMe}\right)_{2}\left(\mathrm{~N}^{\wedge} \mathrm{N}\right)_{2}\right](\mathbf{2 a - 2 c})\right)^{15 \mathrm{a}, \mathrm{d}}$ that contain the aminopyridinate or amidinate ligands 1a-1c represented in Figure 1. As shown in Scheme 1, treatment of the bis(pyridylamido) complex 2a, that has 2,6-i $\mathrm{Pr}_{2} \mathrm{C}_{6} \mathrm{H}_{3}$ and 2,6- $-\mathrm{Me}_{2} \mathrm{C}_{6} \mathrm{H}_{3}$ substituents at the amido nitrogen and pyridinic ring, respectively, with ca. 2.5 mol-equivalent of LiMe occurred with displacement of one of the acetate ligands to form complex 3 a. The complex was obtained as very air sensitive red crystals in $c a .50 \%$ yield (after crystallization).

\section{Scheme 1. Synthesis of complex za}

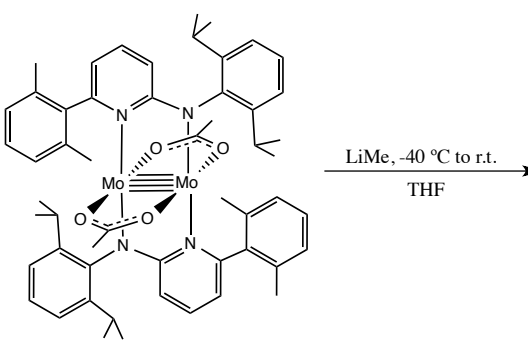

2a

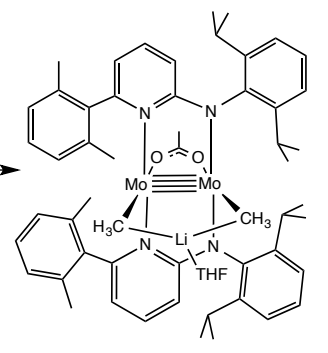

Attempts to replace the remaining acetate employing another mol-equiv of LiMe proved unsuccessful and the use of a large excess of LiMe ( 10 equiv) led to the permethylated complex $\mathrm{Mo}_{2} \mathrm{Me}_{8}{ }^{{ }^{-}}$, previously isolated as the lithium salt. ${ }^{22}$

The molecular complexity of za was ascertained by $\mathrm{X}$-ray crystallography and will be discussed later together with analogous studies carried out for the related complexes $\mathbf{3} \mathbf{b}$ and $\mathbf{4} \mathbf{c}$. It was also determined by NMR spectroscopy that demonstrated the presence of a fivemembered $\mathrm{Mo}_{2}\left(\mathrm{CH}_{3}\right)_{2} \mathrm{Li}$ ring. Formation of $3 \mathrm{a}$ implies a change in the coordination of the aminopyridinate ligands in comparison with precursor $\mathbf{2 a}$, as in the former the two $\mathrm{N}_{\text {amido }}$ and the two $\mathrm{N}_{\mathrm{py}}$ donor atoms are placed in mutually trans positions whereas in the latter each $\mathrm{N}_{\text {amido }}$ is trans with respect to a $\mathrm{N}_{\mathrm{pyr}}$ donor atom. This structural peculiarity is presently being investigated in the parent $\left[\mathrm{Mo}_{2}\left(\mu-\mathrm{O}_{2} \mathrm{CR}\right)_{2}\left(\mu-\mathrm{Ap}^{\prime}\right)_{2}\right]$ compounds (Ap' will be utilized as shorthand notation for an aminopyridinate ligand) and will not be discussed further in this paper. With reference to the $\mathrm{Li}(\mu-\mathrm{Me})_{2} \mathrm{Mo}_{2}$ fragment, only a broad, shielded signal with $\delta-0.41 \mathrm{ppm}$ appears in the ${ }^{1} \mathrm{H}$ NMR spectrum $\left(25^{\circ} \mathrm{C}, \mathrm{C}_{6} \mathrm{D}_{6}\right.$ solvent) due to accidental degeneracy of the non-equivalent methyl resonances. Nevertheless, the ${ }^{13} \mathrm{C}\left\{{ }^{1} \mathrm{H}\right\}$ NMR spectrum (Figure 3) features two well-defined resonances with chemical shifts 4.5 and -1.4 ppm that appear as $c a$. 1:1:1:1 quartets due to coupling to the ${ }^{7} \mathrm{Li}$ nucleus ( $\mathrm{I}=3 / 2$, $92.5 \%$ natural abundance; ${ }^{1} \mathrm{LiC}=$ $12 \mathrm{~Hz}$ ). Furthermore, rather low and approximately equal

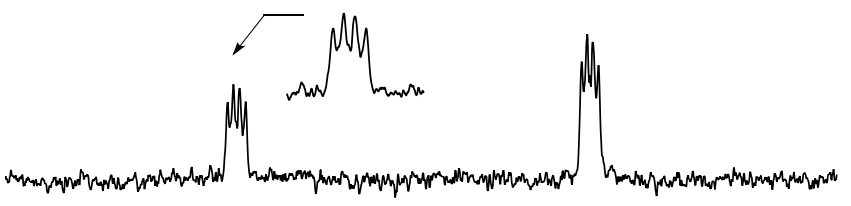

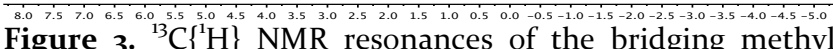
groups of the $\mathrm{Li}(\mu-\mathrm{Me})_{2} \mathrm{Mo}_{2}$ unit of complex $3 \mathrm{a}$.

${ }^{1} J_{\mathrm{CH}}$ couplings of $112 \mathrm{~Hz}$ were measured in the ${ }^{1} \mathrm{H}$-coupled ${ }^{13} \mathrm{C}$ NMR experiment. Although additional experimental and theoretical information on this interesting bonding problem will be discussed in posterior sections of this article, the NMR data recorded for za, in particular: (i) the observation of shielded ${ }^{1} \mathrm{H}$ and ${ }^{13} \mathrm{C}$ resonances for the methyl groups of the $\mathrm{Mo}_{2} \mathrm{Me}_{2} \mathrm{Li}$ unit; (ii) the ${ }^{13} \mathrm{C}-{ }^{7} \mathrm{Li}$ scalar 
coupling of $12 \mathrm{~Hz}$, comparable to that observed for the tetrameric molecules of $[\mathrm{Lit} B \mathrm{Bu}]_{4}(11 \mathrm{~Hz})^{23}$; and (iii) the somewhat reduced ${ }^{13} \mathrm{C}^{1} \mathrm{H}$ coupling of $112 \mathrm{~Hz}$, are in agreement with some electron-density sharing between the two molybdenum-bound $\mathrm{CH}_{3}$ groups and the lithium cation and therefore with the existence of 3-center 2-electron (3c-2e) agostic bonds. ${ }^{24,25}$ Another piece of NMR data that is worth noting is the appearance of a broad singlet centred at $2.15 \mathrm{ppm}$ in the ${ }^{7} \mathrm{Li}$ spectrum recorded in $\mathrm{C}_{6} \mathrm{D}_{6}$. As discussed later for the related compounds $\mathbf{3} \mathbf{b}$ and $\mathbf{3} \mathbf{c}$, this observation provides additional support for the formulation of complex $3 \mathbf{a}$ in its solution in $\mathrm{C}_{6} \mathrm{D}_{6}$ or other non-solvating hydrocarbon solvents as a contact ion pair, ${ }^{26}$ a structure that persists in the solid state (see below).

We also studied the reaction of the analogous bis(acetate)bis(aminopyridinate) complex $\mathbf{2 b}$, that contains the aminopyridinate ligand $\mathbf{l b}$ of Figure $\mathbf{1}$. The latter possesses a 2,6- $-\mathrm{Me}_{2} \mathrm{C}_{6} \mathrm{H}_{3}$ aryl as substituent of the amido nitrogen atom instead of the $2,6-i \mathrm{Pr}_{2} \mathrm{C}_{6} \mathrm{H}_{3}$ aryl of $\mathbf{1 a}$, causing the steric bulkiness of $\mathbf{2} \mathbf{b}$ to be slightly reduced in comparison with $2 \mathbf{a}^{\text {ab,e }}$ Interestingly, the use of $\mathbf{2} \mathbf{b}$ permitted replacement of the two acetate ligands with formation of the trimethyl dimolybdate lithium complex $\mathbf{3} \mathbf{b}$ (vide infra).

Despite initial expectations, no reaction was observed at room temperature between complex $\mathbf{2} \mathbf{b}$ and a small excess of LiMe (1:3.5 molar ratio). However, after stirring at $60{ }^{\circ} \mathrm{C}$ for a total of 18 hours the desired product was isolated in ca. $65 \%$ yield in the form of dark red crystals (Scheme 2). The related bis(acetate)bis(amidinate) compound $2 \mathrm{c}$ reacted similarly with LiMe, although milder experimental conditions were needed (room temperature; ca. $15 \%$ molar excess of LiMe) to yield the expected complex $3 \mathrm{c}$ in $\mathrm{ca} \mathbf{5 2} \%$ isolated yield (Scheme 3). Interestingly, the use of a 1:2 molar ratio of dimolybdenum complex $\mathbf{2 C}$ versus methyl lithium led exclusively to the trimethylated complex $3 \mathbf{c}$ accompanied by unreacted $\mathbf{2 c}$.

Compounds $\mathbf{3 b}$ and $\mathbf{3 c}$ are extremely reactive towards traces of water and oxygen both in solution and in the solid state. For this reason, their solutions degraded rapidly, limiting their manipulation for extended periods of time. Solution NMR data in $\mathrm{C}_{6} \mathrm{D}_{6}$ for the new compounds $\mathbf{3 b}$ and $\mathbf{3 c}$ strongly support their formulation as contact ion pairs. Nevertheless, at variance with $\mathbf{3 a}$, complexes $\mathbf{3} \mathbf{b}$ and $3 \mathbf{c}$ contain a bridging methyl group which behaves as a $\mu$-LX ligand and participates in a $3 c-2 e$ bond. ${ }^{25}$ Besides, the $\mathrm{Mo}_{2}$ unit forms two $\sigma \mathrm{Mo}-\mathrm{C}$ bonds with the methyl groups that interact with the lithium cation through their $\mathrm{C}-\mathrm{H}$ bonds, in close analogy to the bonding situation described above for complex 3a. The $\mathrm{Li}(\mu-\mathrm{Me}) \mathrm{Mo}(\mu-\mathrm{Me}) \mathrm{Mo}(\mu-\mathrm{Me})$ central core of compound 3b was firstly characterized by NMR methods and confirmed afterwards by X-ray crystallography. However, as briefly mentioned, single crystals of the amidinate complex could only be obtained in the presence of tetrahydrofuran and were shown by NMR studies in this solvent and by X-ray crystallography to correspond to the solvent separated complex $4 \mathbf{c}$ with formulation $\left[\mathrm{Li}(\mathrm{THF})_{4}\right]\left[\mathrm{Mo}_{2} \mathrm{Me}_{2}(\mu-\mathrm{Me})\left\{\mu-\mathrm{HC}(\mathrm{NDipp})_{2}\right\}_{2}\right] \quad$ (Dipp = 2,6-i $\mathrm{Pr}_{2} \mathrm{C}_{6} \mathrm{H}_{3}$ ) (vide infra). To authenticate beyond any doubt the central trimethyl heterotrimetallic $\mathrm{Li}(\mu-\mathrm{Me}) \mathrm{Mo}(\mu-\mathrm{Me}) \mathrm{Mo}(\mu-\mathrm{Me})$ core in complex zc, samples of this compound enriched in ${ }^{13} \mathrm{C}$ in the metal-bonded methyl ligands were obtained and investigated by NMR spectroscopic techniques, both in $\mathrm{C}_{6} \mathrm{D}_{6}$ and THF- $d_{8}$ solvents.

Scheme 2. Synthesis of the lithium trimethyldimolybdenum(II) complex 3 b
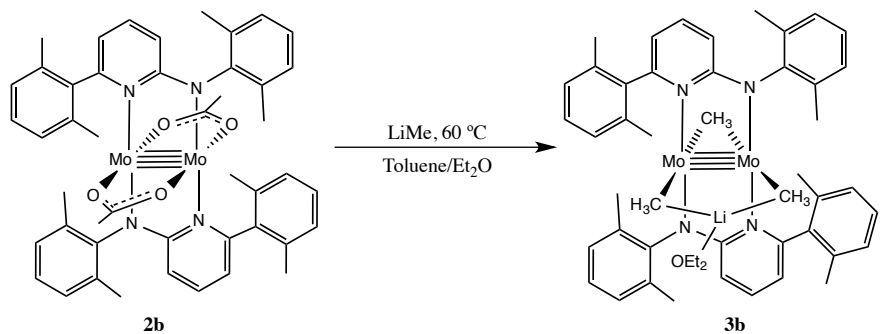

The ${ }^{1} \mathrm{H}$ NMR spectrum of compound $\mathbf{3} \mathbf{b}$ dissolved in $\mathrm{C}_{6} \mathrm{D}_{6}$ hints the presence of a molecule of $\mathrm{Et}_{2} \mathrm{O}$ that completes the coordination of the $\mathrm{Li}^{+}$ion. In addition, resonances with chemical shifts 0.71 and $-1.35 \mathrm{ppm}$ and relative intensity suitable for three and six hydrogen atoms, respectively, were recorded for the $\mathrm{Mo}-\mathrm{CH}_{3}$ groups. The more shielded one is due to the more polar $\mathrm{Mo}_{2}(\mu-\mathrm{Me})_{2} \mathrm{Li}$ methyl protons that, in accordance with the proposed formulation, are related by a $C_{2}$ axys of symmetry (Scheme 2), whereas the other can be attributed to the methyl group that bridges the two molybdenum atoms. The corresponding ${ }^{13} \mathrm{C}$ signals appear at $\delta 6.5$ and $2.8 \mathrm{ppm}$ and present one-bond ${ }^{13} \mathrm{C}-{ }^{1} \mathrm{H}$ couplings of 115 and $110 \mathrm{~Hz}$, respectively. The latter signal is broad as a result of unresolved coupling to the ${ }^{7} \mathrm{Li}$ nucleus.

Scheme 3. Synthesis of the amidinate methyl complex 3c

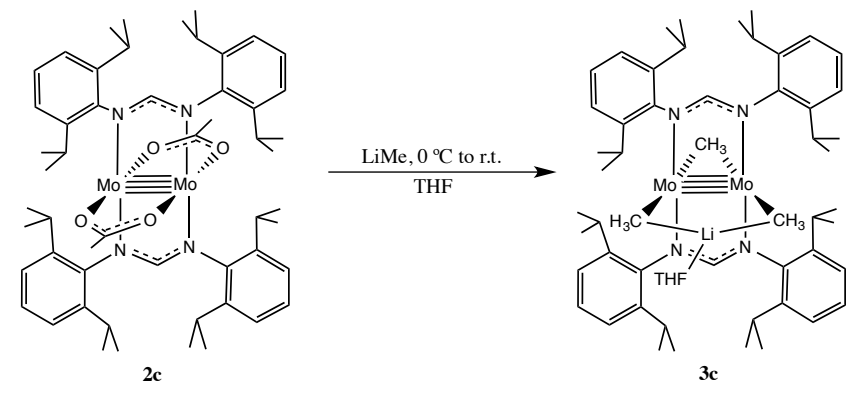

The contact ion pair complex $3 c$ contains a molecule of THF coordinated to lithium, as suggested by ${ }^{1} \mathrm{H}$ NMR studies. In consequence, it has formulation $\left[\mathrm{Mo}_{2}(\mu-\right.$ $\left.\mathrm{Me})\left\{(\mu-\mathrm{Me})_{2} \mathrm{Li}(\mathrm{THF})\right\}\left\{\mu-\mathrm{HC}(\mathrm{NDipp})_{2}\right\}_{2}\right]$. Its characteristic $C_{2 v}$ molecular symmetry (Scheme 3 ) causes the appearance of four doublets for the methyl protons of the iso-propyl amidinate substituents and hence two septets for the corresponding $\mathrm{CHMe}_{2}$ methyne protons (data in $\mathrm{C}_{6} \mathrm{D}_{6}$; see Experimental Section for details). The ${ }^{1} \mathrm{H}$ NMR singlet at $\delta 2.21 \mathrm{ppm}$ originated by the acetate groups in 
the complex precursor $\mathbf{2 c}$ is replaced in $\mathbf{3 c}$ by two signals, one centred at $1.74(\mathrm{~s} ; 3 \mathrm{H})$ and the other at $-0.55(\mathrm{br} \mathrm{s} ; 6$ $\mathrm{H}) \mathrm{ppm}$, respectively ascribed to the $\mathrm{Mo}(\mu-\mathrm{Me}) \mathrm{Mo}$ and $\mathrm{Mo}_{2}(\mu-\mathrm{Me})_{2} \mathrm{Li}$ hydrogen nuclei. These alkyl groups give rise to ${ }^{13} \mathrm{C}\left\{{ }^{1} \mathrm{H}\right\}$ resonances with $\delta 7.14$ and 4.4 ppm, respectively. Although the latter is poorly resolved, a one-bond ${ }^{13} \mathrm{C}-{ }^{7} \mathrm{Li}$ coupling constant of roughly $8 \mathrm{~Hz}$ can be estimated. While its magnitude is somewhat lower than corresponding value for $3^{\mathbf{a}}(12 \mathrm{~Hz})$, the observed coupling is once more indicative of some covalency in the $\mathrm{CH}_{3} \cdots \mathrm{Li} \cdots \mathrm{CH}_{3}$ interactions. In agreement with the above data, the ${ }^{7} \mathrm{Li}$ nucleus resonates as a broad singlet with $\delta$ 2.51 ppm (data also in $\mathrm{C}_{6} \mathrm{D}_{6}$ ) i.e. with chemical shift similar to that of $3 a(2.15 \mathrm{ppm})$.

As briefly noted, complementary NMR studies were undertaken using also $\mathrm{THF}-d_{8}$ as the solvent and with specimens of $3 \mathrm{c}$ enriched in ${ }^{13} \mathrm{C}(99 \%)$ in the metal-bound methyl groups. The labeled samples were prepared as in Scheme 3, but using $\mathrm{Li}^{13} \mathrm{CH}_{3}$, obtained from commercial ${ }^{13} \mathrm{CH}_{3} \mathrm{I}(99 \%)$ and LinBu. Figure $\mathrm{S}_{1}$ (see the Supporting Information) shows the $\mathrm{C}_{6} \mathrm{D}_{6}{ }^{13} \mathrm{C}\left\{{ }^{1} \mathrm{H}\right\}$ NMR spectra of $3 \mathrm{C}$ with natural abundance and labeled with ${ }^{13} \mathrm{C}$, in the $\delta$ interval from ca. 9 to $2 \mathrm{ppm}$, along with the fully coupled spectrum. As can be seen, the singlet at $\delta 7.4$ attributed to $\mathrm{Mo}\left(\mu-\mathrm{CH}_{3}\right)$ Mo converts in the spectrum of the ${ }^{13} \mathrm{C}$ enriched sample into a triplet $\left({ }^{2} J_{\mathrm{CC}}=8 \mathrm{~Hz}\right)$ as a consequence of its coupling with the two equivalent $\mathrm{Mo}_{2}(\mu$ $\left.{ }^{13} \mathrm{CH}_{3}\right)_{2}$ Li nuclei. ${ }^{27}$ The resonance due to the latter methyl groups $(4.4 \mathrm{ppm})$ does not change appreciably. For the two kinds of bridging methyl groups similar ${ }^{1} J_{\mathrm{CH}}$ couplings of about $112 \mathrm{~Hz}$ can be measured.

NMR studies of $3 \mathrm{c}$ in $\mathrm{THF}-d_{8}$ revealed some distinct changes. For instance, the ${ }^{7} \mathrm{Li}$ resonance is now more shielded and appears at -0.1 ppm, thereby shifting by $\sim 2.6$ ppm relative to the spectrum recorded in $\mathrm{C}_{6} \mathrm{D}_{6}$. Changes in the ${ }^{1} \mathrm{H}$ NMR spectrum are not significant beyond some variations in the chemical shifts of the two types of methyl groups that change from 1.74 and -0.55 in $\mathrm{C}_{6} \mathrm{D}_{6}$ to 1.25 and -0.25 ppm in THF- $d_{8}$. However, the broad ${ }^{13} \mathrm{C}\left\{{ }^{1} \mathrm{H}\right\}$ resonance at $4.4 \mathrm{ppm}$ due to the $\mathrm{Mo}(\mu-\mathrm{Me}) \operatorname{Li}(\mu-\mathrm{Me}) \mathrm{Mo}$ linkage in $\mathrm{C}_{6} \mathrm{D}_{6}$ disappears in THF- $d_{8}$ and converts into a sharp singlet with $\delta 14.74$, i.e. displaced towards higher frequency by more than $10 \mathrm{ppm}$. No signs of coupling to ${ }^{7} \mathrm{Li}$ can be detected. The $\mathrm{Mo}(\mu$-Me)Mo signal is also deshielded and appears at $10.43 \mathrm{ppm}(\Delta \delta \sim 3.3 \mathrm{ppm})$. In the specimens enriched in ${ }^{13} \mathrm{C}$, these resonances appear in THF $-d_{8}$ as a doublet $(\delta 14.74)$ and a triplet $(10.43 \mathrm{ppm})$. A single two-bond coupling constant ${ }^{2} \mathrm{~J}_{\mathrm{CC}}=9 \mathrm{~Hz}$ was measured for 4c between the two terminal $\mathrm{Mo}-{ }^{13} \mathrm{CH}_{3}$ groups and the single bridging methyl group of the $\mathrm{Mo}(\mu-$ ${ }^{13} \mathrm{CH}_{3}$ )Mo linkage. The magnitude of this coupling lies between typical values for cis and trans two-bond ${ }^{13} \mathrm{C}-{ }^{13} \mathrm{C}$ couplings in other transition metal complexes. ${ }^{[27]}$ All these data unequivocally support the occurrence in THF solutions of an anionic $\left[\mathrm{Mo}_{2} \mathrm{Me}_{3}\right]^{-}$organometallic core with the simplified structure represented in Figure 2 (structure 4c), and therefore with a solvent separated ion pair formulation $\left[\mathrm{Li}(\mathrm{THF})_{4}\right] \quad\left[\mathrm{Mo}_{2} \mathrm{Me}_{2}(\mu-\mathrm{Me})\{\mu-\right.$
$\left.\mathrm{HC}(\mathrm{NDipp})_{2}\right\}_{2}$ ] for this complex. This proposal has been confirmed by X-ray studies performed with a singlecrystal obtained from concentrated toluene/tetrahydrofuran (1:1) solutions of the complex.

As discussed above, the adoption of the contact ion pair formulation $3 \mathrm{c}$ or the solvent separated ion pair structure 4C is strongly dependent upon the coordination capacity of the solvent. As an additional test, a fresh sample of complex 3c, prepared as in Scheme 3, was dissolved in $\mathrm{C}_{6} \mathrm{D}_{6} .{ }^{1} \mathrm{H}$ and ${ }^{13} \mathrm{C}\left\{{ }^{1} \mathrm{H}\right\}$ NMR studies were in accord with the presence of the (THF) Li( $(\mu-\mathrm{Me}) \mathrm{Mo}(\mu-\mathrm{Me}) \mathrm{Mo}(\mu-\mathrm{Me})$ core characteristic of the contact ion pair structure. Then, the solvent was evaporated under vacuum and the solid residue dissolved in THF- $d_{8}$. NMR analysis $\left({ }^{1} \mathrm{H}\right.$ and ${ }^{13} \mathrm{C}\left\{{ }^{1} \mathrm{H}\right\}$ experiments) revealed the expected features for a monoanionic [MeMo( $\mu$-Me)MoMe] $]^{-}$central unit and the fully solvated $\left[\mathrm{Li}(\mathrm{THF})_{4}\right]^{+}$ion characteristic of $4 \mathbf{c}$. Finally, removal of the solvent under vacuum with careful drying of the residue and re-dissolving of the resulting solid in $\mathrm{C}_{6} \mathrm{D}_{6}$ restored the NMR features of $3 \mathrm{c}$.

Compounds $\mathbf{3 a}, \mathbf{3 b}$, and $\mathbf{4 c}$ were characterized by X-ray crystallography and their molecular structures are depicted in Figures 4 (3a and $3 \mathbf{b}$ ) and 6 (4c). Complete details of the crystallographic analyses are collected in Tables S1-3 (see the Supporting Information). Of the three compounds investigated, the two that exhibit a Mo( $\mu$-Me)Mo $3 \mathbf{c}-2 \mathrm{e}$ bond (i.e. $\mathbf{3 b}$ and $4 \mathbf{c}$ ) have almost identical Mo-Mo bond lengths (ca. 2.084 $\AA$ ) whereas in the acetate-bridged species za the metal-metal bond is slightly longer at 2.107(6) A. These values are very close to those reported recently for terphenyl complexes of the Mo $\equiv$ Mo central unit. $^{14}$

As can be seen in Figure 4, the two Ap' ligands of complexes $\mathbf{3} \mathbf{a}$ and $\mathbf{3} \mathbf{b}$ (ligands $\mathbf{1 a}$ and $\mathbf{1 b}$ in Figure 1, respectively) adopt different stereochemical distribution upon binding to the respective $\mathrm{Mo}_{2}$ cores. Thus, in compound $3 \mathrm{a}$ the two $\mathrm{N}_{\text {pyr }}$ and the two $\mathrm{N}_{\text {amido }}$ nitrogen atoms are mutually trans while in complex $3 \mathbf{b}$ they give rise to trans $-\mathrm{N}_{\text {amido }}-\mathrm{Mo}-\mathrm{N}_{\mathrm{py}}$ linkages, as it is commonly observed in dichromium complexes with $\mathrm{Cr}-\mathrm{Cr}$ multiple bonds. ${ }^{11}$ In the two compounds, the dative covalent Mo- $\mathrm{N}_{\mathrm{py}}$ bonds are longer than the normal covalent ${ }^{25} \mathrm{Mo}-\mathrm{N}_{\text {amido }}$ bonds. Thus, in $3 \mathrm{a}$ the average $\mathrm{Mo}-\mathrm{N}_{\mathrm{py}}$ and Mo- $\mathrm{N}_{\text {amido }}$ bond lengths are of ca. $\mathbf{2 . 2 1}$ and $2.14 \AA$, respectively, whereas the similar bonds of $\mathbf{3}$ b are of about 2.18 and $2.11 \AA$. 

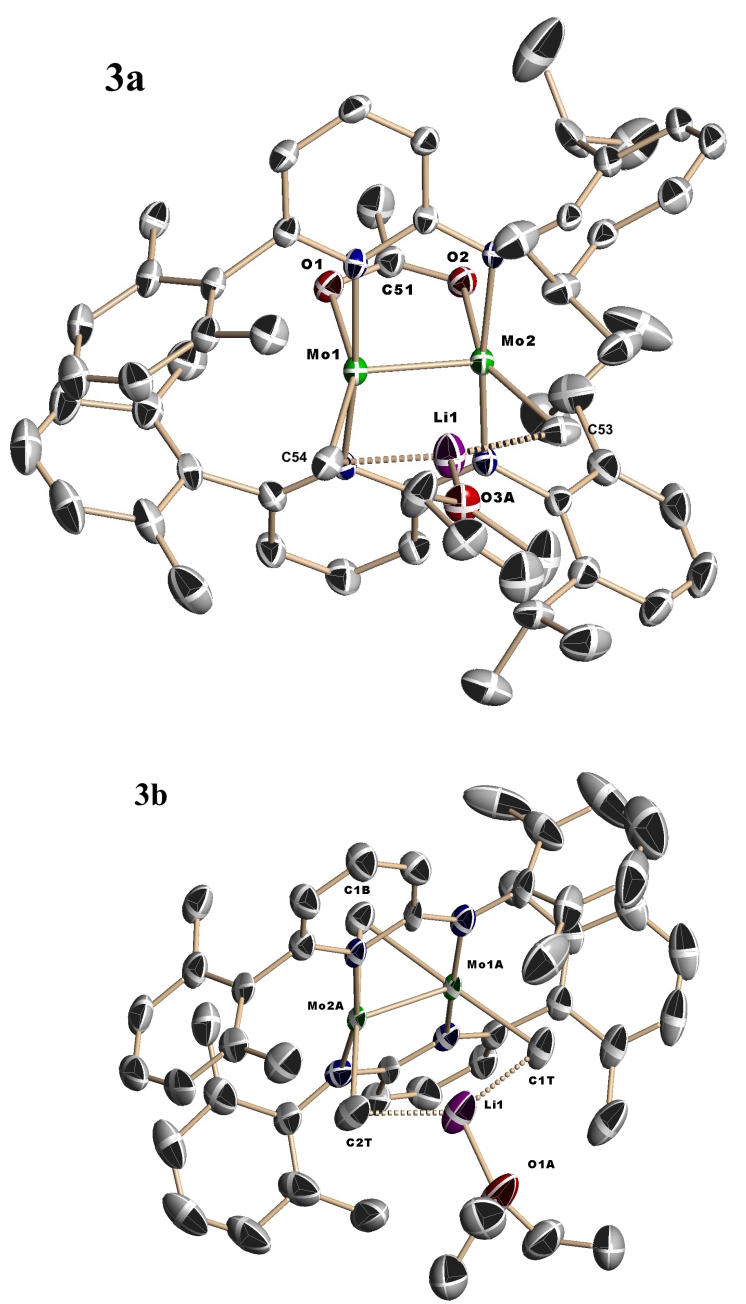

Figure 4. Solid-state molecular structures of complexes za (above) and $\mathbf{3 b}$ (below), with thermal ellipsoids set at $30 \%$ probability. Selected bond lengths in $\AA$ 3a: $\operatorname{Mo}(1)-\operatorname{Mo}(2)$, 2.107(1); $M o(1)-C(54)$, 2.218(5); $M o(2)-C(53), 2.216(5)$; $C(54)-$ $\mathrm{Li}(1)$, 2.08o(1); C(53)-Li(1), 2.143(3). 3b: $\operatorname{Mo}(1 \mathrm{~A})-\mathrm{Mo}(2 \mathrm{~A})$, 2.084(8); $\operatorname{Mo}(1 \mathrm{~A})-\mathrm{C}(1 \mathrm{~T}), 2.273(8) ; \operatorname{Mo}(2 \mathrm{~A})-\mathrm{C}(2 \mathrm{~T}), 2.251(7)$; $\operatorname{Mo}(2 \mathrm{~A})-\mathrm{C}\left({ }_{1} \mathrm{~B}\right), 2.411(7) ; \operatorname{Mo}(1 \mathrm{~A})-\mathrm{C}\left({ }_{1} \mathrm{~B}\right), 2.404(8) ; \mathrm{C}(2 \mathrm{~T})-\mathrm{Li}(1)$, $2.162(6) ; C(1 T)-\operatorname{Li}(1), 2.160(5)$.

The two complexes contain a $\mathrm{CH}_{3} \cdots \operatorname{Li}(\mathrm{S}) \cdots \mathrm{CH}_{3}$ unit that spans over the Mo-Mo quadruple bond ( $\mathrm{S}=\mathrm{THF}$ for za and $\mathrm{Et}_{2} \mathrm{O}$ for $3 \mathbf{b}$ ). The $\mathrm{Mo}_{2} \mathrm{C}_{2} \mathrm{Li}$ five-membered ring is close to planar, although the lithium atom deviates by 0.428 and $0.249 \AA$, respectively, from the mean plane of the two molybdenum and the two carbon atoms. Dihedral angles between the $\mathrm{C}-\mathrm{Mo}-\mathrm{Mo}-\mathrm{C}$ and $\mathrm{C}-\mathrm{Li}-\mathrm{C}$ planes are of $32^{\circ}$ for $3 \mathbf{a}$ and $21^{\circ}$ for $3 \mathbf{b}$. The five-membered rings contain comparable Mo-C bonds with average lengths of ca. 2.21 (3a) and $2.26 \AA$ (3b). For comparison, $\mathrm{Mo}-\mathrm{CH}_{3}$ distances in the quadruply bonded anionic complex $\mathrm{Mo}_{2} \mathrm{Me}_{8}^{4-}$ have values ${ }^{22}$ in the range 2.27-2.31 $\AA$, while in neutral $\mathrm{Mo}_{2} \mathrm{Me}_{4}\left(\mathrm{PR}_{3}\right)_{4}$ molecules the $\mathrm{Mo}-\mathrm{CH}_{3}$ bonds have a length of roughly $2.24 \AA \AA^{20 c, d}$ Typical Mo-Me distances in compounds compiled in the CSD are in the 2.10-2.36 range. ${ }^{21}$

For complexes $3 \mathbf{a}$ and $\mathbf{3} \mathbf{b}$ the hydrogen atoms of the Mo- $\mathrm{CH}_{3}$ groups were located on a difference Fourier map. Nevertheless, to ensure a uniform treatment of crystal data they were recalculated into idealized positions. In accordance with the experimental data obtained, it can be proposed that in the two complexes the coordination requirements of the lithium ion are partly satisfied by the existence of weak dihapto agostic interactions (Figure 5 and $\mathrm{S}_{2}$; see the Supporting Information) with the molybdenum-bonded methyl groups.

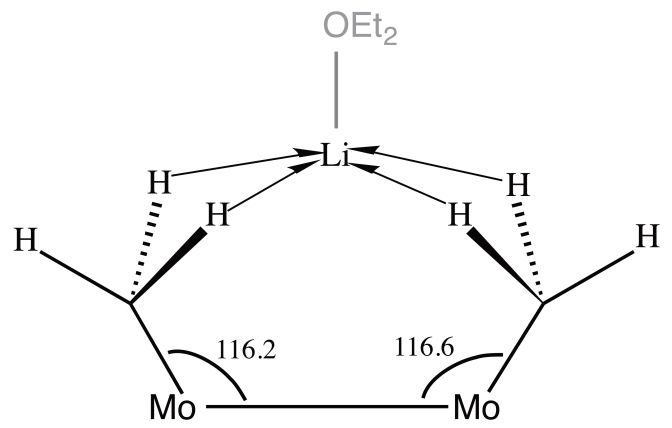

Figure 5. Schematic representation of the dihapto agostic $\mathrm{Mo}_{2}\left(\mu-\mathrm{CH}_{3}\right)_{2} \mathrm{Li}$ interactions in complex $3 \mathbf{b}$. The $\mathrm{Li}-\mathrm{CH}_{3}$ distances have a value of $c a .2 .16 \AA$ and the $\mathrm{Li} \cdots \mathrm{H}$ contacts are in the approximate range 1.83-2.11 $\AA$. Angles are in degrees $\left(^{\circ}\right)$. See also Figure $\mathrm{S}_{2}$ in the Supporting Information for additional details.

Agostic $\mathrm{M}-\mathrm{CH}_{3} \cdots \mathrm{Li}$ interactions have been ascertained for different transition metals. ${ }^{28-31}$ In complex $3 a$ the two $\mathrm{Li}-\mathrm{C}$ bonds of the $\mathrm{CH}_{3} \cdots \mathrm{Li} \cdots \mathrm{CH}_{3}$ portion of the five-membered $\mathrm{Mo}_{2} \mathrm{C}_{2} \mathrm{Li}$ ring are slightly different and distinctly short $(2.080(1)$ and $2.143(3) \AA$ ) whereas in 3 b they are practically identical and also short (ca. 2.16 $\AA$ ). As a reference, the sum of the covalent radii of $C_{\mathrm{sp}}{ }^{3}$ (o.76 $\AA$ ) and $\mathrm{Li}(1.28 \AA)$ is $2.04 \AA .^{32}$ These metrics denote the existence in the molecules of $3 \mathbf{a}$ and $\mathbf{3} \mathbf{b}$ of non-negligable covalent $3 \mathrm{c}-2 \mathrm{e}$ interactions, as hinted by the solution NMR data already discussed. These interactions seem to be comparable to those found in related complexes. For instance, Gambarotta and co-workers demonstrated that $[\mathrm{Li}(\mathrm{S})]_{4}\left[\mathrm{Cr}_{2} \mathrm{Me}_{8}\right]\left(\mathrm{S}=\mathrm{Et}_{2} \mathrm{O}\right.$, THF $)$ can be reversibly cleaved by action of tmed (tmed = tetramethylethylenediamine) with formation of $[\mathrm{Li}(\mathrm{tmed})]_{2}\left[\mathrm{CrMe}_{4}\right],{ }^{33}$ and proposed that short $\mathrm{Li} \cdots \mathrm{CH}_{3}$ bonding interactions of 2.176 (7) $\AA$ were responsible for holding together the two $\mathrm{CrMe}_{4} \mathrm{Li}_{2}$ units of the dimer. The latter, originally characterized by Krausse, ${ }^{34}$ features a short $\mathrm{Cr}-\mathrm{Cr}$ distance of 1.968 (2) $\AA^{, 3{ }^{3 b}}$ but recently, Mulvey et al. have demonstrated that replacing $\mathrm{Li}^{+}$by $\mathrm{Na}^{+}$in $\left[\mathrm{Na}\left(\mathrm{OEt}_{2}\right)\right]_{4}\left[\mathrm{Cr}_{2} \mathrm{Me}_{8}\right]$ caused the $\mathrm{Cr}-\mathrm{Cr}$ separation to increase to 3.263 (2) $\AA . .^{35}$ Interestingly, the isostructural $[\mathrm{Li}(\mathrm{THF})]_{4}\left[\mathrm{Mo}_{2} \mathrm{Me}_{8}\right]$ complex ${ }^{22}$ could not be cleaved under reaction conditions similar or harder than those employed for the dichromium complex. ${ }^{33}$ In the latter dimolybdenum compound the lithium ions lie at distances of 2.43-2.56 $\AA$ from the methyl carbon atoms. It is also worth pointing out that in the two complexes $3^{a}$ and $3 \mathbf{b}$ the Mo $\cdots \mathrm{Li}$ contacts are long, in the range 2.872(2)-2.962(9) A, indicating that there are no significant bonding interactions between these atoms. Recently, Tsai et al. have reported studies on a complex with a Mo-Mo quintuple bond spanned by one lithium atom 
with Mo $\cdots$ Li contacts of $2.640(8) \AA$ that were considered as mainly ionic. ${ }^{36}$ It is important to recall that compounds alike $\mathbf{3} \mathbf{a}$ and $\mathbf{3} \mathbf{b}$ that exhibit a bridging hydrocarbyl $\mathrm{M}(\mu-$ $\mathrm{R}) \mathrm{M}^{\prime}$ structure between transition metal and main group metal atoms are of much current importance, as they are relevant to a number of catalytic reactions, for instance, olefin oligo- and polymerization, cyclizations and addi tions of carbonyl and alkyl functionalities, and different classes of cross-coupling processes. ${ }^{29,37-39}$

The coordination of the molybdenum atoms of $3^{\mathbf{a}}$ is completed by a bidentate acetate ligand, while that in $\mathbf{3 b}$ involves instead a bridging methyl group that participates in a $3 \mathrm{c}-2 \mathrm{e}$ interaction. The two kinds of bridging ligands can be viewed as LX ligands thereby yielding a sixteenelectron count at each molybdenum centre, as it is commonly encountered in complexes of this type. ${ }^{10}$ Bridging alkyl groups are well-known, although they are much less frequently found that bridging hydride ligands. ${ }^{25,40-45} \mathrm{Ex}-$ amples in which the bridging alkyls span over multiple $\mathrm{M}-\mathrm{M}$ bonds are however sparse $\mathrm{e}^{1 \mathrm{e}, 46-49}$ and correspond largely to dichromium complexes. The anionic compound 4c features also a bridging methyl group (Figure 6). It crystallizes in the $C_{2 / c}$ monoclinic space group with two independent molecules in the asymmetric unit (arbitrarily designated as $\mathbf{B}$ and $\mathbf{C}$ ). The two display the same geometry and feature similar structural parameters, particularly in what concerns the Mo-Mo and Mo-N bonds. However, their organometallic $(\mu-\mathrm{Me}) \mathrm{Mo}_{2} \mathrm{Me}_{2}$ moieties exhibit small differences that merit discussion.

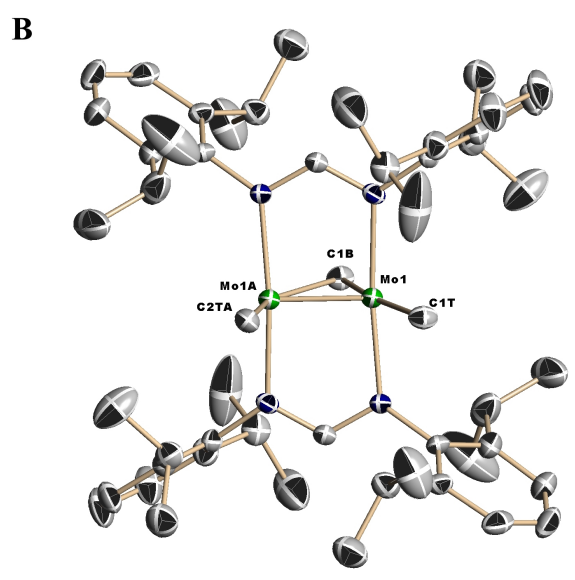

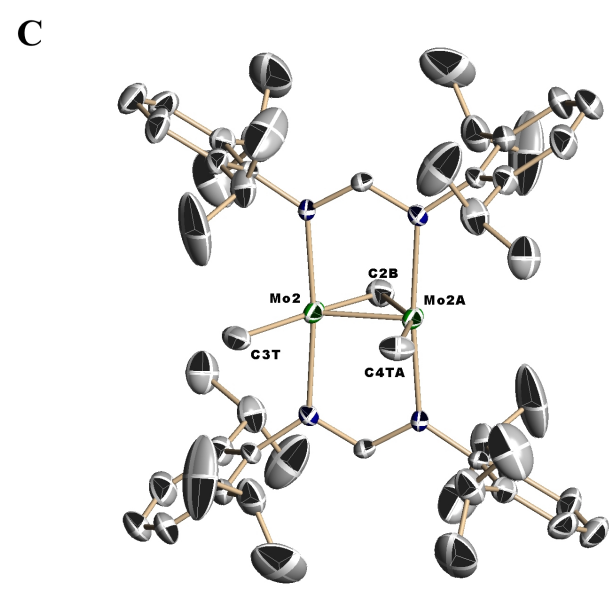

Figure 6. Solid-state molecular structure of the anionic $\left[\mathrm{Mo}(\mathrm{Me})_{2}(\mu-\mathrm{Me})\left\{\mu-\mathrm{HC}(\mathrm{NDipp})_{2}\right\}_{2}\right]^{-}$portion of complex $4 \mathrm{C}$ showing the two independent molecules, $\mathbf{B}$ (bottom) and $\mathbf{C}$ (upper structure). The counter-cation $\left[\mathrm{Li}(\mathrm{THF})_{4}\right]^{+}$has been omitted for clarity. Thermal ellipsoids are set at 30\%. Selected bond lengths in $\AA$ 4c (B): $\operatorname{Mo}(1 A)-M o(1), 2.084(1)$; $\operatorname{Mo}\left({ }_{1} A\right)$ C(2TA), 2.396(1); $\operatorname{Mo}\left({ }_{1} A\right)-C(2 T A), 2.397(1) ; \operatorname{Mo}(1 \mathrm{~A})-C(1 \mathrm{~B})$, 2.172(1); $\operatorname{Mo}(1)-C(1 B), 2.411(7)$. (C): $\operatorname{Mo}(2)-\operatorname{Mo}(2 \mathrm{~A}), 2.083(1)$; $\operatorname{Mo}(2)-C(3 \mathrm{~T}), \quad 2.429(1) ; \quad \operatorname{Mo}(2 \mathrm{~A})-\mathrm{C}(4 \mathrm{TA}), \quad 2.473(1) ; \quad \operatorname{Mo}(2)-$ $\mathrm{C}(2 \mathrm{~B}), 2.328(1) ; \mathrm{Mo}(2 \mathrm{~A})-\mathrm{C}(2 \mathrm{~B}), 2.157(7)$.

In $\mathbf{3} \mathbf{b}$ the bridging methyl group is appropriately described as symmetric pyramidal with essentially identical Mo-C bond distances (ca. 2.40 $\AA$ ) and C-Mo-Mo angles (about $64^{\circ}$ ), and with a more acute Mo-C-Mo angle of $51.3(2)^{\circ}$ (Figure 7 ). The long $\mathrm{Mo}-\mathrm{C}_{1} \mathrm{~B}$ bonds are possibly the consequence of the strong trans influence ${ }^{50}$ exerted by the two molybdenum-bound methyl groups ( $\mathrm{C}_{1} \mathrm{~T}$ and $\mathrm{C}_{2} \mathrm{~T}$ ) that form regular Mo-C bonds (ca. 2.26 $\AA$ ) and hold together the lithium ion. The $\mathrm{C}_{1} \mathrm{~T}-\mathrm{Mo1} \mathrm{A}-\mathrm{C}_{1} \mathrm{~B}$ and $\mathrm{C}_{2} \mathrm{~T}-\mathrm{Mo} 2 \mathrm{~A}-\mathrm{C}_{1} \mathrm{~B}$ bond angles of $178.4(3)$ and $178.8(3)^{\circ}$, respectively, are very close to the ideal $180^{\circ}$ value.

For the two independent molecules of $\mathbf{4} \mathbf{C}$ (B and C, Figure 7) there are two terminal methyl groups that form long Mo-Me bonds (in the range 2.396(1) - 2.473(1) $\AA$ ). Moreover, they give rise to Mo-Mo-C angles with divergent values, one being of roughly $98^{\circ}$ and the other of about $116^{\circ}$. The bridging methyl group generates an acute Mo-C-Mo angle (ca. $53^{-}-55^{\circ}$ ) and two Mo-C bonds that differ appreciably in length. Thus, in molecules $\mathbf{B}$ the Mo-C distances are of 2.172(1) and 2.452(1), a situation that therefore approaches terminal coordination to Mo1 (Figure 7), ${ }^{11 e, 49 c}$ whereas in $\mathbf{C}$ the differences are smaller (2.157(1) and 2.328(1) $\AA$ ). Although the hydrogen atoms of the bridging methyl groups were not located in the Fourier difference map, they were calculated, these calculations supporting a weak monohapto agostic coordination. Whether the agostic interaction is maintained in solution is unclear since as discussed above, the terminal and bridging methyl groups of complex $\mathbf{4 c}$ exhibit close ${ }^{1} J_{\mathrm{CH}}$ couplings of 115 and $112 \mathrm{~Hz}$, respectively $\left(\mathrm{THF}-d_{8}\right.$ ). We note, however, that similar ${ }^{13} \mathrm{C}-{ }^{1} \mathrm{H}$ couplings in Mo-Mo bonded complexes with a bridging methyl group have led 
to divergent interpretations on the possible existence of agostic interactions. ${ }^{46}$

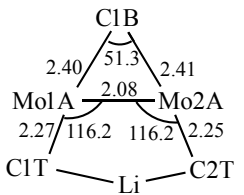

C1T-Mo1A-C1B $=178.4$ C2T-Mo2A-C1B $=178.8$

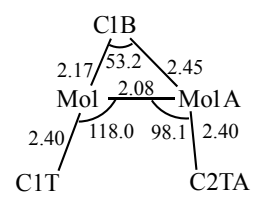

C1T-Mo1-C1B $=171.7$ C2TA-Mo1A-C1B $=154.5$

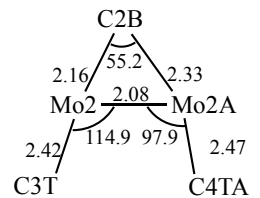

C3T-Mo2-C2B $=177.2$ C4TA-Mo2A-C2B =156.1

$4 \mathrm{c}(\mathrm{C})$
Figure 7. Bond lengths $(\AA)$ and bond angles $\left({ }^{\circ}\right)$ for the organometallic $\left[\mathrm{Mo}_{2} \mathrm{Me}_{3}\right]$ cores of complexes $3 \mathbf{b}$ (left) and $4 \mathbf{c}$ (independent molecules $\mathbf{B}$, centre, and $\mathbf{C}$, right). For simplicity, bond distances have been rounded up to the second decimal figure and bond angles to the first.

Computational studies on the $\operatorname{Moz}(\mu-\mathrm{Me})_{2} \mathrm{Li}$ linkage of complexes $3 a$ and $3 b$

The gas phase geometries of $3 \mathbf{a}_{\mathrm{C}}$ (with the $i \operatorname{Pr}$ fragments of $\mathbf{3} \mathbf{a}$ replaced by Xylyl groups) and $\mathbf{3 b}$ were optimized at the DFT level with the Gaussian $09^{51}$ package, using the $\mathrm{Mo6}^{52}$ and PBEo-D $3^{53}$ functionals, which account for dispersion effects. The optimizations were done with the basis set 6-3ig $(\mathrm{d}, \mathrm{p})$ for light atoms and the SDD basis and associated Electron Core Potential for Mo. Both methods reproduce the solid state geometry of $\mathbf{3 a}$ and $\mathbf{3} \mathbf{b}$, particularly the short $\mathrm{CH}_{3} \cdots \mathrm{Li}$ contacts (Tables $\mathrm{S}_{22}-\mathrm{S}_{25}$ ) of the $\mathrm{Mo}_{2}(\mu-\mathrm{Me})_{2} \mathrm{Li}$ linkage.

The extent of bonding interaction between the methyl groups and the lithium atoms of $\mathbf{3} \mathbf{a}$ and $\mathbf{3} \mathbf{b}$ was studied by means of the quantum theory of atoms in molecules (QTAIM). ${ }^{54}$ Analysis of the calculated electron densities $(\rho)$ of $3 \mathbf{a}_{\mathbf{C}}$ and $\mathbf{3} \mathbf{b}$ with the Multiwfn program ${ }^{55}$ reveals bond critical points (bcps) and unique bond paths (bp) between each carbon and the lithium atoms of their $\mathrm{Mo}_{2}(\mu-\mathrm{Me})_{2} \mathrm{Li}$ linkages (Figures 8 and S6). Accordingly some level of electron sharing between these carbon atoms and their attached hydrogens with the lithium atom becomes apparent by the analysis as discussed below.

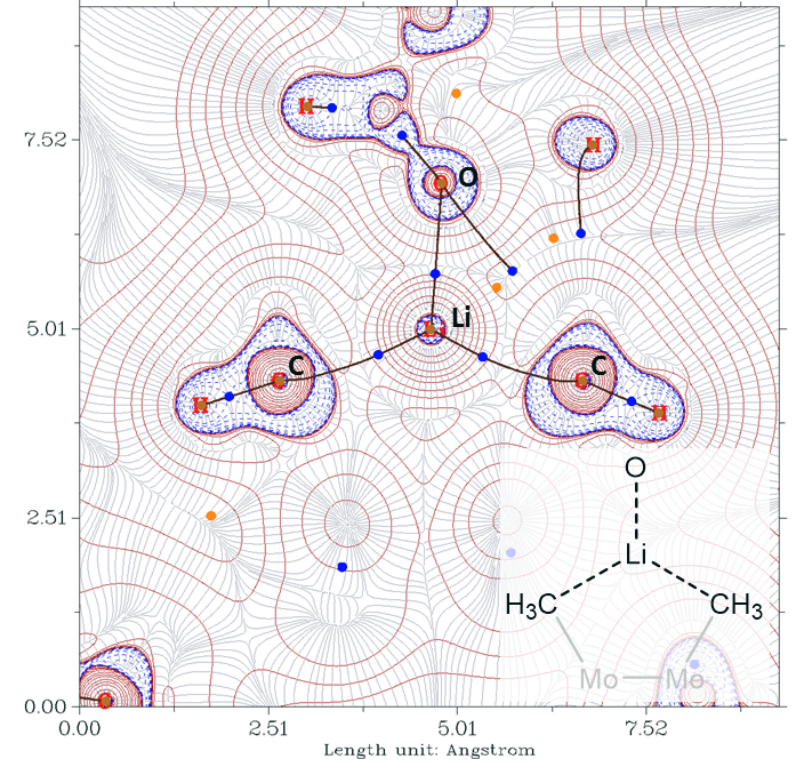

Figure 8. Plot of the laplacian of the electron density $\nabla^{2} \rho$ of $3 \mathbf{a}_{\mathrm{C}}$ in the $\mathrm{C}_{\mathrm{Mo}}, \mathrm{C}_{\mathrm{Mo}}$, Li plane calculated with the Mo6 functional. The solid and dashed lines correspond to positive and negative values of $\nabla^{2} \rho$ respectively. In-plane bcps and bond paths of the electron density are superimposed.

The presence of a unique bond path with a bond critical point connecting two atoms is usually invoked as one (but not exclusive) ${ }^{56}$ criterion of interacting atoms. Besides, the topological properties of the electron density at the bond critical points have been related to the nature of the interaction between atoms. ${ }^{57,58}$ Tables 1 and $\mathrm{S}_{4}$-S8 summarize topological properties at selected bcps of $3 \mathbf{a}_{\mathrm{c}}$ and $\mathbf{3} \mathbf{b}$. These data are consistent with an important ionic character for the C...Li interactions in these molecules, similar to that found in MeLi (see the SI for details and the criteria used). In agreement with this classification the electron density integrated in the basins of the lithium atoms (the AIM or Bader charges) is close to o.ge as expected for $\mathrm{Li}^{+}$. However this result suggests a small but non-negligible degree of electron sharing between the basins of lithium and the neighboring atoms in agreement with the ${ }^{1} \mathrm{JiC}_{\text {Li }}$ observed by NMR.

Table 1. QTAIM analysis of the electron density of $3 \mathrm{a}_{C}$ at selected bcps.

\begin{tabular}{|l|l|c|c|l|}
\hline Bond & $\rho^{c}$ & $H_{b}{ }^{d}=V_{b}+G_{b}$ & $\left|V_{b}\right| / G_{b}$ & $\nabla^{2} \rho^{\mathbf{e}}$ \\
\hline C-Li $^{\mathbf{b}}$ & 0.0226 & 0.0033 & 0.8800 & 0.1228 \\
\hline Li-O & 0.0267 & 0.0080 & 0.7933 & 0.1879 \\
\hline Mo-Mo & 0.1796 & -0.1094 & 1.5012 & 0.4233 \\
\hline Mo-C $^{\mathbf{b}}$ & 0.0840 & -0.0250 & 1.4056 & 0.1449 \\
\hline
\end{tabular}

acalculations with the Mo6 functional, ${ }^{b}$ (average values of the local total energy density $\boldsymbol{H}_{\mathrm{b}}$ as the sum of the local potential $\boldsymbol{V}_{\mathbf{b}}$ and kinetic energies $\boldsymbol{G}_{\mathbf{b}}$, ${ }^{\mathrm{c}} \mathrm{e} \cdot \mathrm{bohr}{ }^{-3}$, ${ }^{\mathrm{d}}$ hartree, e e.bohr ${ }^{-5}$.

In relation with the above, delocalization indices $(\delta(A, B))$ indicate the number of electron pairs shared 
(delocalized) between two atoms A and B, and can be seen as a type of topological order of a bond. ${ }^{57-59}$ In our case covalent $\mathrm{C}-\mathrm{H}$ interactions have $\delta(\mathrm{C}, \mathrm{H})$ close to 1 , and $\delta(\mathrm{Mo}, \mathrm{Mo})$ are almost 3 for both molecules considered whereas the delocalization indices for the C...Li interactions are in the range between 0.05 and 0.06 , slightly smaller than the values found for the $\mathrm{Li} \ldots \mathrm{O}$ interactions (Tables $\mathrm{S}_{9}-\mathrm{S}_{17}$ ), which are in the range between 0.06 and o.07.

A complementary approach to explain the electron sharing between the methyl carbons and lithium atoms of 3 consists on applying the orbital-based Natural Bonding Orbitals scheme. ${ }^{60}$ In this case localized orbitals are derived from molecular orbitals to yield the best Lewis-like bonding description of molecules. Interactions between non-covalently bonded fragments of a molecule are accounted for by delocalizations of two (or three) center populated orbitals into empty antibonding or lone pair (localized on one atom) orbitals. ${ }^{61}$ In our case the interaction between the $\mathrm{Li}$ atom and the organometallic fragment of complexes 3 is described in terms of delocalizations of Mo-Mo and Mo-C orbitals onto empty orbitals localized on the lithium (see Figures S8-S9 and Tables S18-S19). In addition Wiberg bond indices derived from the NBO analysis support the bonding situation depicted in Figure 5, (Tables S20-21), with values close to o,1 for the C...Li interaction and around 0.01-0.o2 for the four hydrogen atoms of the $\mathrm{CH}_{3}$ fragments closer to $\mathrm{Li}$, the latter being three- or fourfold the values found for the hydrogens oriented away from the lithium.

\section{EXPERIMENTAL SECTION}

\section{General considerations}

All manipulations were carried out using standard Schlenk and glove-box techniques, under an atmosphere of argon and of high purity nitrogen, respectively. All solvents were dried and degassed prior to use, and stored over $4 \AA$ molecular sieves. Toluene $\left(\mathrm{C}_{7} \mathrm{H}_{8}\right)$, n-pentane $\left(\mathrm{C}_{5} \mathrm{H}_{12}\right)$, and $n$-hexane $\left(\mathrm{C}_{6} \mathrm{H}_{14}\right)$ were distilled under nitrogen over sodium. Tetrahydrofuran (THF) and diethyl ether were distilled under nitrogen over sodium/benzophenone. Benzene- $d^{6}$ and THF- $d^{8}$ were distilled under argon over sodium/benzophenone; $\left[\mathrm{D}_{8}\right]$ toluene was distilled under argon over sodium. The quadruply bonded $\mathrm{Mo}_{2}\left(\mathrm{O}_{2} \mathrm{CMe}\right)_{2}\left(\mathrm{~N}^{\wedge} \mathrm{N}\right)_{2}$ complexes $\mathbf{2 a - 2 c}$ were prepared as described previously. ${ }^{15 \mathrm{a}, \mathrm{d}}$ Solution NMR spectra were recorded on Bruker AMX-300, DRX-400 and DRX-500 spectrometers. Spectra were referenced to external $\mathrm{SiMe}_{4}(\delta:$ o ppm) using the residual proton solvent peaks as internal standards ( ${ }^{1} \mathrm{H}$ NMR experiments), or the characteristic resonances of the solvent nuclei $\left({ }^{13} \mathrm{C}\right.$ NMR experiments), while ${ }^{7} \mathrm{Li}$ was referenced to external $\mathrm{LiCl}$. Spectral assignments were made by routine one- and two-dimensional NMR experiments $\left({ }^{1} \mathrm{H},{ }^{13} \mathrm{C},{ }^{13} \mathrm{C}\left\{{ }^{1} \mathrm{H}\right\}\right.$, COSY, NOESY, HSQC and $\mathrm{HMBC}$ ) where appropriate. UV-visible spectra were recorded on a PerkinElmer Lambda 750 spectrometer. For elemental analyses a LECO TruSpec CHN elementary analyzer, was utilized.

\section{Synthesis and characterization of compound za}

To a suspension of the corresponding $\left[\mathrm{Mo}_{2}\left(\mathrm{O}_{2} \mathrm{CMe}\right)_{2}\left(\mathrm{Ap}^{\prime}\right)_{2}\right]$ complex, 2a, (6oo mg, o.58 mmol) in THF (ca. $12 \mathrm{~mL}$ ) cooled to $-40^{\circ} \mathrm{C}$, LiMe ( 2.5 equiv) was added slowly. The low temperature was kept for about 3 hours and then the reaction mixture was allowed to reach room temperature with continuous stirring during 3 hours giving a red solution that was evaporated in vacuo. The solid residue was extracted with pentane (ca. $35 \mathrm{~mL}$ ) and was centrifuged. The filtrate was transferred to a Schlenk tube, concentrated and stored at $-23{ }^{\circ} \mathrm{C}$ during 2 days. Dark red crystals of complex za separated out and were isolated by filtration and dried under vacuum for 2 hours. Yield: $320 \mathrm{mg}$ (50\%). ${ }^{1} \mathrm{H}$ NMR (500 MHz, $\mathrm{C}_{6} \mathrm{D}_{6}, 25$ $\left.{ }^{\circ} \mathrm{C}\right): \delta=-0.41$ (br. s, $\left.6 \mathrm{H},\left\{\mathrm{Mo}_{2} \mathrm{Me}_{2} \mathrm{Li} \cdot \mathrm{THF}\right\}\right), 0.97(\mathrm{~d}, 6 \mathrm{H}$, $\mathrm{Me}_{\text {Dipp }}\left(\right.$ endo) ), 1.12 (d, $6 \mathrm{H}, \mathrm{Me}_{\text {Dipp }}($ endo $\left.)\right), 1.19$ (m, $4 \mathrm{H}, \mathrm{O}-$ $\left.\mathrm{CH}_{2} \mathrm{CH}_{2}\right), 1.27\left(\mathrm{~d}, 6 \mathrm{H},{ }^{3} \mathrm{JHH}_{\mathrm{HH}}=6.8 \mathrm{~Hz}, \mathrm{Me}_{\text {Dipp }}(\right.$ exo $\left.)\right), 1.28(\mathrm{~d}$, $\left.6 \mathrm{H}, \mathrm{Me}_{\text {Dipp }}^{\prime}(\mathrm{exo})\right), 2.05$ (s, $\left.6 \mathrm{H}, \mathrm{Me}_{\mathrm{Xyl}}^{\prime}\right), 2.21$ (s, $3 \mathrm{H}$, $\mathrm{CH}_{3} \mathrm{CO}_{2}$ ), 2.31 (s, $6 \mathrm{H}, \mathrm{Me}_{\mathrm{Xyl}}$ ), 3.23 (sept, $2 \mathrm{H}, \mathrm{CH}^{\prime} \mathrm{Me}_{2}$ ), 3.39 (m, $4 \mathrm{H}, \mathrm{O}-\mathrm{CH}_{2} \mathrm{CH}_{2}$ ), 3.44 (sept, $2 \mathrm{H}, \mathrm{CHMe}$ ), 5.76 (dd, 2 $\left.\mathrm{H},{ }^{3} J_{\mathrm{HH}}=8.7 \mathrm{~Hz},{ }^{4} J_{\mathrm{HH}}=1.2 \mathrm{~Hz}, 5-\mathrm{py}\right), 6.47\left(\mathrm{dd}, 2 \mathrm{H},{ }^{3} J_{\mathrm{HH}}=\right.$ $\left.8.7 \mathrm{~Hz},{ }^{4} J_{\mathrm{HH}}=1.2 \mathrm{~Hz}, 3-\mathrm{py}\right), 6.67\left(\mathrm{dd}, 2 \mathrm{H},{ }^{3} J_{\mathrm{HH}}=8.7 \mathrm{~Hz}\right.$, ${ }^{4} J_{\mathrm{HH}}=6.7 \mathrm{~Hz}, 4-\mathrm{py}$ ), 6.71 (virtual t, $4 \mathrm{H},{ }^{3} J_{\mathrm{HH}}=7.6 \mathrm{~Hz}, m-$ $\mathrm{Xyl}$ and $\left.m^{\prime}-\mathrm{Xyl}\right), 6.85\left(\mathrm{t}, 2 \mathrm{H},{ }^{3} J_{\mathrm{HH}}=7.6 \mathrm{~Hz}, p-\mathrm{Xyl}\right)$, 7.17-7.22 (m, $6 \mathrm{H}, m^{\prime}$-Dipp, $m$-Dipp, and $p$-Dipp) ppm. The coupling constants ${ }^{3} \mathrm{~J}_{\mathrm{HH}}$ for all $\mathrm{CHMe}_{2}$ groups are approximately of $7 \mathrm{~Hz} .{ }^{1} \mathrm{H}$ signals with ' refer to the group located in the same region as the MeLiMe unit. ${ }^{13} \mathrm{C}\left\{{ }^{1} \mathrm{H}\right\}$ NMR (125 MHz, $\left.\mathrm{C}_{6} \mathrm{D}_{6}, 25{ }^{\circ} \mathrm{C}\right): \delta=-1.4,4.5$ (q, $1 \mathrm{C}$ each, $\left.{ }^{1} J\left({ }^{13} \mathrm{C},{ }^{7} \mathrm{Li}\right)=12 \mathrm{~Hz},\left\{\mathrm{Mo}_{2} \mathrm{Me}_{2} \mathrm{Li} \cdot \mathrm{THF}\right\}\right), 20.3\left(\mathrm{Me}_{\mathrm{Xyl}}^{\prime}\right), 21.0$ $\left(\mathrm{Me}_{\mathrm{Xyl}}\right), 22.9\left(\mathrm{CH}_{3} \mathrm{CO}_{2}\right), 24.5\left(\mathrm{Me}_{\text {Dipp }}(\right.$ endo $\left.)\right), 24.8(\mathrm{O}-$ $\left.\mathrm{CH}_{2} \mathrm{CH}_{2}\right), 25.3,25.5\left(\mathrm{Me}_{\text {Dipp }}(\mathrm{exo})\right.$ and $\mathrm{Me}_{\text {Dipp }}($ exo $\left.)\right), 25.8$ $\left(\mathrm{Me}_{\text {Dipp }}(\right.$ endo $\left.)\right), 27.9\left(\mathrm{CHMe}_{2}\right), 28.4\left(\mathrm{CH}^{\prime} \mathrm{Me}_{2}\right), 68.2(\mathrm{O}-$ $\mathrm{CH}_{2} \mathrm{CH}_{2}$ ), 108.2 (5-py), 112.5 (3-py), 124.2 (m-Dipp), 124.5 ( $m$ '-Dipp), 125.0 (p-Dipp), 126.4 ( $m^{\prime}$-Xyl), 128.2 ( $p$-Xyl), 128.5 (m-Xyl), 130.9 (4-py), 135.9, 136.0 (o-Xyl), 139.7 (ipsoXyl), 144.1 (o'-Dipp), 145.8 (o-Dipp), 146.9 (ipso-Dipp), $157.7,169.5$ (6-py and 2-py), 177.3 $\left(\mathrm{O}_{2} \mathrm{CCH}_{3}\right)$. The signals with' refer to the group located in the same region as the MeLiMe unit. ${ }^{7} \mathrm{Li}$ NMR (194 MHz, $\left.\mathrm{C}_{6} \mathrm{D}_{6}, 25{ }^{\circ} \mathrm{C}\right): \delta=\mathbf{2 . 1 5}$ (br. s) ppm. UV/visible $\left(\mathrm{C}_{6} \mathrm{H}_{14}\right): \lambda_{\max }(\varepsilon)=255$ and 340,420 and $505 \mathrm{~nm}$ (3100, 600o $\mathrm{M}^{-1} \mathrm{~cm}^{-1}$, respectively). Elemental analysis calcd. (\%) for $\mathrm{C}_{58} \mathrm{H}_{75} \mathrm{LiMo}_{2} \mathrm{~N}_{4} \mathrm{O}_{3}$ : C, 64.80; H, 7.03; N, 5.21. Found: C, 64.9; H, 6.9; N, 5.0.

\section{Synthesis and characterization of compound 3 b}

The appropriate $\left[\mathrm{Mo}_{2}\left(\mathrm{O}_{2} \mathrm{CMe}\right)_{2}\left(\mathrm{Ap}^{\prime}\right)_{2}\right]$ complex (2b) (1.0 g, $1.1 \mathrm{mmol}$ ) was dissolved in a toluene/ $/ \mathrm{Et}_{2} \mathrm{O}$ (2:1) mixture and LiMe ( 3 equiv) was added. The solution was heated at $60^{\circ} \mathrm{C}$ for 6 hours. Then, another 3 equiv of LiMe were added and the resulting mixture was heated for a further period of 12 hours at $60{ }^{\circ} \mathrm{C}$. The suspension was centrifuged, the filtrate was transferred to a Schlenk tube and the solvent was removed under vacuum. Diethyl ether (ca. $10 \mathrm{~mL}$ ) was added and the solution was kept in the fridge for 3 days to obtain dark red crystals of complex 3b in $65 \%$ yield. ${ }^{1} \mathrm{H}$ NMR ( $\left.400 \mathrm{MHz}, \mathrm{C}_{6} \mathrm{D}_{6}, 25{ }^{\circ} \mathrm{C}\right): \delta=-1.35$ 
(s, $\left.6 \mathrm{H},\left\{\mathrm{Me}_{2} \mathrm{Li} \cdot \mathrm{Et}_{2} \mathrm{O}\right\}\right), 0.77(\mathrm{~s}, 3 \mathrm{H}, \mathrm{m}-\mathrm{Me}), 2.02(\mathrm{~s}, 6 \mathrm{H}$, $\mathrm{Me}_{\mathrm{Xyl}}$ ), 2.05 (s, $6 \mathrm{H}, \mathrm{Me}_{\mathrm{Xyl}}(\mathrm{amino})$ ), 2.20 (s, $6 \mathrm{H}, \mathrm{Me}_{\mathrm{Xyl}(\mathrm{amino})}$ ), $2.24\left(\mathrm{~s}, 6 \mathrm{H}, \mathrm{Me}_{\mathrm{Xyl}}\right), 6.06\left(\mathrm{~d}, 2 \mathrm{H},{ }^{4} J_{\mathrm{HH}}=6.5 \mathrm{~Hz}, 5-\mathrm{py}\right.$, ), $6.46\left(\mathrm{~d}, 2 \mathrm{H},{ }^{3} J_{\mathrm{HH}}=7.5 \mathrm{~Hz}, m^{\prime}-\mathrm{Xyl}\right), 6.49\left(\mathrm{~d}, 2 \mathrm{H},{ }^{3} J_{\mathrm{HH}}=7.5\right.$ $\mathrm{Hz}, m-\mathrm{Xyl}), 6.57\left(\mathrm{t}, 2 \mathrm{H},{ }^{3} J_{\mathrm{HH}}=7.5 \mathrm{~Hz}, p-\mathrm{Xyl}\right), 6.73(\mathrm{~d}, 2 \mathrm{H}$, $\left.{ }^{4} J_{\mathrm{HH}}=8.9 \mathrm{~Hz}, 3-\mathrm{py}\right), 6.92-7.02\left(\mathrm{~m}, 6 \mathrm{H}, m-\mathrm{Xyl}_{(\mathrm{amino})}, p^{-}\right.$ $\mathrm{Xyl}_{(\mathrm{amino})}$, and 4-py), 7,07 (m, $\left.2 \mathrm{H}, \mathrm{m}^{\prime}-\mathrm{Xyl}_{(\mathrm{amino})}\right) \mathrm{ppm} .{ }^{1} \mathrm{H}$ signals with ' refer to the group located in the same region as the MeLiMe unit. Signals corresponding to aryl (ArN-) are marked with amino. ${ }^{13} \mathrm{C}\left\{{ }^{1} \mathrm{H}\right\}$ NMR (100 $\mathrm{MHz}, \mathrm{C}_{6} \mathrm{D}_{6}, 25$ $\left.{ }^{\circ} \mathrm{C}\right): \delta=2.8$ (br. s, $\left.\left\{\mathrm{Me}_{2} \mathrm{Li}_{\mathrm{E}} \mathrm{Et}_{2} \mathrm{O}\right\}\right), 6.5$ (m-Me), 20.2 $\left(\mathrm{Me}_{\mathrm{Xyl}(\mathrm{amino})}\right), \quad 21.7,21.8 \quad\left(\mathrm{Me}_{\mathrm{Xyl}}(\mathrm{amino})\right.$ and $\left.\mathrm{Me}_{\mathrm{Xyl}}\right), 22.4$ $\left(\mathrm{Me}_{\mathrm{Xyl}}{ }^{\prime}\right), 107.9$ (5-py), 110.7 (3-py), 124.6 (p-Xyl $\left.{ }_{(\mathrm{amino})}\right), 127.6$ (m'-Xyl), 128.6 (under signal $\mathrm{C}_{6} \mathrm{D}_{6}, m-\mathrm{Xyl}, p$-Xyl), 129.0, $129.2\left(m^{\prime}-\mathrm{Xyl}_{(\mathrm{amino})}\right.$ and $\left.m-\mathrm{Xyl}_{(\mathrm{amino})}\right), 132.4$ (4-py), 133.2 (o'$\left.\mathrm{Xyl}_{(\mathrm{amino})}\right), 135.2\left(o-\mathrm{Xyl}_{(\mathrm{amino})}\right), 135.4$ (o-Xyl), 137.3 (o'-Xyl), 140.4 (ipso-Xyl), 148.9 (ipso-Xyl (amino) $_{156.2}$ (6-py), 165.5 (2-py) ppm. The signals with' refer to the group located in the same region as the MeLiMe unit. Signals corresponding to aryl (ArN-) are marked with amino. ${ }^{7} \mathrm{Li}$ NMR $\left(\mathrm{C}_{6} \mathrm{D}_{6}, 194 \mathrm{MHz}\right): \delta=1.72 \mathrm{ppm}$. UV/visible $\left(\mathrm{C}_{7} \mathrm{H}_{8}\right): \lambda_{\max }$ $(\varepsilon)=460,575\left(12535,4685 \mathrm{M}^{-1} \mathrm{~cm}^{-1}\right.$, respectively). Elemental analysis calcd. (\%) for $\mathrm{C}_{49} \mathrm{H}_{61} \mathrm{LiMo}_{2} \mathrm{~N}_{4} \mathrm{O}$ : C, 63.91; H, 6.68; N, 6.08. Found: C, 63.9; H, 6.6; N, 5.7.

\section{Synthesis and characterization of compound $3 \mathrm{C}$}

Complex $\left.\left[\mathrm{Mo}_{2}\left(\mathrm{O}_{2} \mathrm{CMe}\right)_{2}\right)\left\{\mu-\mathrm{HC}(\mathrm{NDipp})_{2}\right\}_{2}\right]$ (2c) (4.o g, $3.86 \mathrm{mmol}$ ) was dissolved in THF $(60 \mathrm{~mL})$. The mixture was cooled at $\mathrm{o}^{\circ} \mathrm{C}$ and LiMe ( 3.5 equiv) was added slowly. The reaction mixture was allowed to reach room temperature over a period of 12 hours. The resulting red suspension was centrifuged, the filtrate was transferred to a Schlenk flask and the solvent was removed under vacuum. Pentane was added (10 $\mathrm{mL})$, the suspension was stirred for 5-10 min and the solvent was removed in vacuo. This process was repeated one more time and the resulting solid was dried under vacuum for four hours to obtain a red solid (2.5 g, ca. 6o\%). ${ }^{1} \mathrm{H}$ NMR (50o MHz, $\mathrm{C}_{6} \mathrm{D}_{6}, 25$ $\left.{ }^{\circ} \mathrm{C}\right): \delta=-0.55$ (br. s, $\left.6 \mathrm{H},\left\{\mathrm{Mo}_{2} \mathrm{Me}_{2} \mathrm{Li} \cdot \mathrm{THF}\right\}\right), 0.98(\mathrm{~d}, 12 \mathrm{H}$, ${ }^{3} J_{\mathrm{HH}}=6.8 \mathrm{~Hz}, \mathrm{Me}_{\mathrm{Dipp}}($ endo $\left.)\right), 1.27\left(\mathrm{~d}, 12 \mathrm{H},{ }^{3} J_{\mathrm{HH}}=6.8 \mathrm{~Hz}\right.$, $\mathrm{Me}_{\text {Dipp }}($ endo) $), 1.32\left(\mathrm{~d}, 12 \mathrm{H},{ }^{3} \mathrm{~J}_{\mathrm{HH}}=6.8 \mathrm{~Hz}, \mathrm{Me}_{\text {Dipp }}(\mathrm{exo})\right)$, $1.35\left(\mathrm{~m}, 4 \mathrm{H}, \mathrm{O}-\mathrm{CH}_{2} \mathrm{CH}_{2}\right), 1.38\left(\mathrm{~d}, 12 \mathrm{H},{ }^{3} \mathrm{~J}_{\mathrm{HH}}=6.8 \mathrm{~Hz}, \mathrm{Me}-\right.$ Dipp (exo)), 1.74 (s, $3 \mathrm{H}, \mu-\mathrm{Me}), 3.55\left(\mathrm{~m}, 4 \mathrm{H}, \mathrm{O}-\mathrm{CH}_{2} \mathrm{CH}_{2}\right.$ ), 3.76 (sept, $4 \mathrm{H},{ }^{3} \mathrm{~J}_{\mathrm{HH}}=6.8 \mathrm{~Hz}, \mathrm{CH}^{\prime} \mathrm{Me}_{2}$ ), 4.11 (sept, $4 \mathrm{H},{ }^{3} J_{\mathrm{HH}}$ $\left.=6.8 \mathrm{~Hz}, \mathrm{CHMe}{ }_{2}\right), 7.02\left(\mathrm{dd}, 4 \mathrm{H},{ }^{3} J_{\mathrm{HH}}=7.6 \mathrm{~Hz},{ }^{4} J_{\mathrm{HH}}=1.6\right.$ Hz, m-Dipp), 7.06 (t, $4 \mathrm{H},{ }^{3} J_{\mathrm{HH}}=7.6 \mathrm{~Hz}, p$-Dipp), 7.11 (dd, $4 \mathrm{H},{ }^{3} J_{\mathrm{HH}}=7.6 \mathrm{~Hz},{ }^{4} J_{\mathrm{HH}}=1.7 \mathrm{~Hz}, m^{\prime}$-Dipp), 8.59 (s, $2 \mathrm{H}$, $\mathrm{NC}(H) \mathrm{N}) \mathrm{ppm} .{ }^{1} \mathrm{H}$ signals with' refer to the group located in the same region as the MeLiMe unit. ${ }^{13} \mathrm{C}\left\{{ }^{1} \mathrm{H}\right\}$ NMR $(125$ $\left.\mathrm{MHz}, \mathrm{C}_{6} \mathrm{D}_{6}, \quad 25{ }^{\circ} \mathrm{C}\right): \delta=4.4\left(\mathrm{~m},{ }^{1} J\left({ }^{13} \mathrm{C},{ }^{7} \mathrm{Li}\right) \sim 8 \mathrm{~Hz}\right.$, $\left.\left\{\mathrm{Mo}_{2} \mathrm{Me}_{2} \mathrm{Li} \cdot \mathrm{THF}\right\}\right), 7.14$ (s, $\mu-\mathrm{Me}$ ), 24.5 ( $\mathrm{Me}_{\mathrm{Dipp}}($ endo) $), 25.0$ ( $\mathrm{Me}_{\text {Dipp }}($ endo $\left.)\right), 25.6\left(\mathrm{O}-\mathrm{CH}_{2} \mathrm{CH}_{2}\right), 26.6\left(\mathrm{Me}_{\text {Dipp }}\right.$ (exo)), 28.4 $\left(\mathrm{CH}^{\prime} \mathrm{Me}_{2}\right), 28.5\left(\mathrm{CHMe}_{2}\right), 28.7$ ( $\left.\mathrm{Me}_{\text {Dipp }}(\mathrm{exo})\right), 124.1,124.2$ ( $m$-Dipp and $m$ '-Dipp), 125.7 ( $p$-Dipp), 143.9 (o'-Dipp), 145.4 (o-Dipp), 143.3 (ipso-Dipp), $161.3(\mathrm{NC}(\mathrm{H}) \mathrm{N})$ ppm. The signals with' refer to the group located in the same region as the MeLiMe unit. ${ }^{7} \mathrm{Li}$ NMR (194 MHz, C 6 D, 25 $\left.{ }^{\circ} \mathrm{C}\right): \delta=2.51$ (br. s, $\left.\left\{\mathrm{Mo}_{2} \mathrm{Me}_{2} \mathrm{Li} \cdot \mathrm{THF}\right\}\right) \mathrm{ppm}$. UV/visible
$\left(\mathrm{C}_{4} \mathrm{H}_{8} \mathrm{O}\right): \lambda_{\max }(\varepsilon)=420 \mathrm{~nm}\left(2200 \mathrm{M}^{-1} \mathrm{~cm}^{-1}\right)$. Elemental analysis calcd. (\%) for $\mathrm{C}_{57} \mathrm{H}_{87} \mathrm{LiMo}_{2} \mathrm{~N}_{4} \mathrm{O}$ (3c): C, 65.63; $\mathrm{H}$, 8.41; N, 5.37. Found: C, 65.2; H, 8.1; N, 5.o.

\section{Synthesis and characterization of compound 4c}

This complex was prepared as indicated above for the contact ion pair complex $3 \mathbf{c}$. After removal of the reaction solvent under vacuum, the obtained crude red solid was crystallized from a saturated THF:toluene solution (1:1) at $-23{ }^{\circ} \mathrm{C}$ for three days. Red crystals of the solvent-separated ion pair complex $\left[\mathrm{Li}(\mathrm{THF})_{4}\right]\left[\mathrm{Mo}_{2} \mathrm{Me}_{2}(\mu-\mathrm{Me})\{\mu-\right.$ $\left.\mathrm{HC}(\mathrm{NDipp})_{2}\right\}_{2}$ ] (4c) were isolated by filtration and dried under vacuum for 2 hours. Selected signals for complex 4c: ${ }^{1} \mathrm{H}$ NMR (500 MHz, THF- $d_{8}, 25{ }^{\circ} \mathrm{C}$ ): $\delta=-0.25$ (br. s, 6 $\mathrm{H},\{M e-M o M o-M e\}), 1.25$ (s, $3 \mathrm{H}, \mu-M e)$ ppm. ${ }^{13} \mathrm{C}\left\{{ }^{1} \mathbf{H}\right\}$ NMR (125 MHz, THF- $\left.d_{8}, 25{ }^{\circ} \mathrm{C}\right): \delta=10.43\left(\mathrm{~s},\left\{\mathrm{Mo}_{2} \mathrm{Me}_{2} \mathrm{Li} \cdot \mathrm{THF}\right\}\right)$, 14.74 (s, $\mu$-Me). ${ }^{7} \mathrm{Li}$ NMR (194 MHz, THF- $\left.d_{8}, 25{ }^{\circ} \mathrm{C}\right): \delta=-$ 0.10 (br. s, $\left\{\mathrm{Mo}_{2} \mathrm{Me}_{2} \mathrm{Li} \cdot \mathrm{THF}\right\}$ ) ppm. Elemental analysis calcd. (\%) for $\mathrm{C}_{69} \mathrm{H}_{111} \mathrm{LiMo}_{2} \mathrm{~N}_{4} \mathrm{O}_{4}$ (4c): C, 65.80; H, 8.88; N, 4.45. Found: C, 66.5; H, 9.6; N, 4.9.

\section{CONCLUSIONS}

We have prepared and structurally characterized newly designed metal-metal bonded complexes that contain a $\mathrm{Mo}_{2}$ core spanned by a $-\mathrm{CH}_{3} \cdots \mathrm{Li} \cdots \mathrm{CH}_{3}-$ fragment. This structural motif is present in compounds $\mathbf{3 a - 3 \mathbf { c }}$ and is made up of two $\mathrm{Mo}-\mathrm{CH}_{3}$ units that are bonded to a solvated lithum cation $(\mathrm{S}) \mathrm{Li}^{+}\left(\mathrm{S}=\mathrm{Et}_{2} \mathrm{O}\right.$ or $\left.\mathrm{THF}\right)$ by means of $3 \mathrm{c}-2 \mathrm{e}$ agostic interactions. The resulting $\mathrm{Mo}_{2} \mathrm{Me}_{2} \mathrm{Li}$ central assembly has a Mo-Mo bond length that is consistent with a Mo-Mo quadruple bond. Each metal atom binds additionally to two nitrogen atoms of two bridging aminopyridinate or amidinate ligands and their coordination is completed by a third bridging ligand, namely acetate for $\mathbf{3} \mathbf{a}$ or methyl in complexes $\mathbf{3} \mathbf{b}$ and $\mathbf{3 c}$. Computational studies on the dimethyl heterotrinuclear $\mathrm{Mo}_{2} \mathrm{Me}_{2} \mathrm{Li}$ framework reveal that the $\mathrm{CH}_{3} \cdots \mathrm{Li}$ interactions are mainly ionic with a non-negligible covalent character which is in agreement with NMR observations.

\section{ASSOCIATED CONTENT}

Experimental procedures and characterization data for other new compounds described herein, CIF files along additional tables and figures with computational details and xyz coordinates of calculated species. This material is available free of charge via the Internet at http://pubs.acs.org.

\section{AUTHOR INFORMATION}

\section{Corresponding Authors}

guzman@us.es

joaquin.lopez@iiq.csic.es

\section{Notes}

The authors declare no competing financial interest. 


\section{ACKNOWLEDGMENTS}

Financial support (FEDER contribution and Subprogramas Juan de la Cierva) from the Spanish Ministry of Science and Innovation (Projects CTQ2010-15833, CTQ2013-42501-P and Consolider-Ingenio 2010 CSD2007-0ooo6) and the Junta de Andalucía (Grant FQM-119 and Project Pog-FQM-5117) is gratefully acknowledged. M.C. and N.C. thank the Spanish Ministry of Education (AP-4193) and the Spanish Ministry of Science and Innovation (BES-2011-047643) for research grants. C.M. thanks the Ministry of Economy and Competitiveness for the project CTQ2014-52769-C3-3-R. J.L.-S. thanks the MICINN and the European Social Fund for the award of a "Ramón y Cajal" contract. The use of computational facilities of the Supercomputing Center of Galicia (CESGA) is also acknowledged.

\section{REFERENCES}

(1) (a) Bochmann, M. Organometallics and Catalysis. An Introduction, Oxford University Press, Oxford, UK, 2015. (b) Crabtree, R. H. The Organometallic Chemistry of the Transition Metals, 6th ed., John Wiley \& Sons, Inc., Hoboken, 2014. (c) Hartwig, J. Organotransition Metal Chemistry: From Bonding to Catalysis, University Science Books, Sausalito, 2010. (d) Elschenbroich, C. Organometallics, 3rd ed., Wiley-VCH, Weinheim, 2006.

(2) (a) Comprenhensive Organometallic Chemistry III, (Ed.: Crabtree, R. H.; Mingos, D. M. P.), Elsevier Ltd, 2007, See Volumes 1 (Ed.: Meyer, K.), 3 (Ed.: Housecrof, C. E.), 9 (Ed.: Knochel, P.), 10 (Ed.: Ojima, I.) and 11 (Ed.: Hiyama, T.). (b) Organometallics in Synthesis, A Manual, (Schlosser, M.), John Wiley \& Sons, Ltd., Chichester, 2002.

(3) (a) Davidson, P. J.; Lappert, M. F.; Pearce, R. Chem. Rev. 1976, 76, 219-242. (b) Schrock, R. R.; Parshall, G. W. Chem. Rev. 1976, 76, 243-268. (c) Holton, J.; Lappert, M. F.; Pearce, R.; Yarrow, P. I. W. Chem. Rev. 1983, 83, 135-201.

(4) Shortland, A. J.; Wilkinson, G. J. Chem. Soc. Dalt. Trans. 1973, $872-876$.

(5) (a) Nguyen, T.; Sutton, A. D.; Brynda, M.; Fettinger, J. C.; Long, G. J.; Power, P. P. Science 2005, 310, 844-847. (b) Wolf, R.; Ni, C.; Nguyen, T.; Brynda, M.; Long, G. J.; Sutton, A. D.; Fischer, R. C.; Fettinger, J. C.; Hellman, M.; Pu, L.; Power, P. P. Inorg. Chem. 2007, 46, 11277-11290.

(6) Willkinson, G. Chimia 1973, 27, 3.

(7) Schrock, R. R. J. Am. Chem. Soc. 1975, 97, 6577-6578.

(8) Bernskoetter, W. H.; Schauer, C. K.; Goldberg, K. I.; Brookhart, M. Science 2009, 326, 553-556.

(9) (a) Stephenson, T. A.; Bannister, E.; Wilkinson, G. J. Chem. Soc. 1964, 2538-2541. (b) Walton, R. A.; Fanwick, P. E.; Girolami, G. S. Inorg. Synth. 2014, 36, 78-81.

(10) (a) Cotton, F. A.; Murillo, C. A.; Walton, R. A. Multiple Bonds between Metal Atoms, 3rd ed., Springer Science And Business Media, Inc., New York, 2005. (b) Chisholm, M. H.; Patmore, N. J. in: Molecular Metal-Metal Bonds, Chapter 6 (Ed.: Liddle, S. T.), Wiley-VCH Verlag GmbH \& Co. KGaA, Weinheim, 2015.

(11) (a) Noor, A.; Glatz, G.; Müller, R.; Kaupp, M.; Demeshko, S.; Kempe, R. Nat. Chem. 2009, 1, 322-325. (b) Wagner, F. R.; Noor, A.; Kempe, R. Nat. Chem. 2009, 1, 529-536. (c) Noor, A.; Wagner, F. R.; Kempe, R. Angew. Chem., Int. Ed. 2oo8, 47, 72467249. (d) Noor, A.; Bauer, T.; Todorova, T. K.; Weber, B.; Gagliardi, L.; Kempe, R. Chem.-Eur. J. 2013, 19, 9825-9832. (e) Noor, A.; Schwarf, S.; Kempe, R. Organometallics, 2015, 34, 21222125. (f) Noor, A.; Kempe, R. Inorg. Chim. Acta 2015, 424, 75-82.

(12) For relevant references on the use of bulky amidinates to stabilize quintuple $\mathrm{Cr}-\mathrm{Cr}$ and Mo-Mo see: (a) Tsai, Y.-C.; Chen,
H.-Z.; Chang, C.-C.; Yu, J.-S. K.; Lee, G.-H.; Wang, Y.; Kuo, T.-S. J. Am. Chem. Soc. 2009, 131, 12534-12535. (b) Tsai, Y.-C.; Hsu, C.W.; Yu, J.-S. K.; Lee, G.-H.; Wang, Y.; Kuo, T.-S. Angew. Chem., Int. Ed. 2008, 47, 7250-7253. (c) Hsu, C.-W.; Yu, J.-S. K.; Yen, C.H.; Lee, G.-H.; Wang, Y.; Tsai, Y.-C. Angew. Chem., Int. Ed. 2oo8, 47, 9933-9936. (d) Huang, Y.-L.; Lu, D.-Y.; Yu, H.-C.; Yu, J.-S. K.; Hsu, C.-W.; Kuo, T.-S.; Lee, G.-H.; Wang, Y.; Tsai, Y.-C. Angew. Chem., Int. Ed. 2012, 51, 7781-7785. (e) Liu, S.-C.; Ke, W.-L.; Yu, J.S. K.; Kuo, T.-S.; Tsai, Y.-C. Angew. Chem., Int. Ed. 2012, 51, 63946397.

(13) (a) Nair, A. K.; Harisomayajula, N. V. S.; Tsai, Y.-C. Dalton Trans. 2014, 43, 5618-5638. (b) Harisomayajula, N. V. S.; Nair, A. K.; Tsai, Y.-C. Chem. Comm. 2014, 50, 3391-3412. (c) Nair, A. K.; Harisomayajula, N. V. S.; Tsai, Y.-C. Inorg. Chim. Acta 2015, 424, 51-62.

(14) (a) Carrasco, M.; Faust, M.; Peloso, R.; Rodríguez, A.; López-Serrano, J.; Âlvarez, E.; Maya, C.; Power, P. P.; Carmona, E. Chem. Commun. 2012, 48, 3954-3956. (b) Carrasco, M.; Mendoza, I.; Faust, M.; López-Serrano, J.; Peloso, R.; Rodríguez, A.; Álvarez, E.; Maya, C.; Power, P. P.; Carmona, E. J. Am. Chem. Soc. 2014, 136, 9173-9180.

(15) (a) Carrasco, M.; Curado, N.; Maya, C.; Peloso, R.; Rodríguez, A.; Ruiz, E.; Alvarez, S.; Carmona, E. Angew. Chem., Int. Ed. 2013, 52, 3227-3231. (b) Carrasco, M.; Curado, N.; Álvarez, E.; Maya, C.; Peloso, R.; Poveda, M. L.; Rodríguez, A.; Ruiz, E.; Álvarez, S.; Carmona, E. Chem.-Eur. J. 2014, 20, 6092-6102. (c) Carrasco, M.; Álvarez, E.; Maya, C.; Peloso, R.; Rodríguez, A.; Falceto, A.; Álvarez, S.; Carmona, E. Chem.-Eur. J. 2015, 21, 410421. (d) Mendoza, I.; Curado, N.; Carrasco, M.; Álvarez, E.; Peloso, R.; Rodíguez, A.; Carmona, E. Inorg. Chim. Acta 2015, 424, 120-128.

(16) (a) Falvello, L. R.; Foxman, B. M.; Murillo, C. A. Inorg. Chem. 2014, 53, 9441-9456. (b) Falvello, L. R.; Murillo, C. Inorg. Chim. Acta 2015, 424, 1-2. Special issue dedicated to metal-metal bonded compounds and clusters.

(17) (a) Krogman, J. P.; Thomas, C. M. Chem. Commun. 2014, 50, 5115-5127. (b) Cooper, B. G.; Napoline, J. W.; Thomas, C. M. Cat. Rev. Sci. Eng. 2012, 54, 1-40. (c) Chisholm, M. Coord. Chem. Rev. 2013, 257, 1576-1583.

(18) (a) Fohlmeister, L.; Shengsi, L.; Schulten, C.; Moubaraki, B.; Stasch, A.; Cashion, J. D.; Murray, K. S.; Gagliardi, L.; Jones, C. Angew. Chem., Int. Ed. 2012, 51, 8294-8298. b) Jones, C.; Schulten, C.; Rose, R. P.; Stasch, A.; Aldridge, S.; Woodul, W. D.; Murray, K. S.; Moubaraki, B.; Brynda, M.; La Macchia, G.; Gagliardi, L. Angew. Chem., Int. Ed. 2009, 48, 7406-7410.

(19) (a) Eisenhart, R. J.; Rudd, P. A.; Planas, N.; Boyce, D. W.; Carlson, R. K,; Tolman, W. B.; Bill, E.; Gagliardi, L.; Lu, C. C. Inorg. Chem. 2015, DOI: 10.1021/acs.inorgchem.5bo1163. (b) Tereniak, S. J.; Carlson, R. K.; Clouston, L. J.; Young, V. G. Jr.; Bill, E.; Maurice, R.; Chen, Y.-S.; Kim, H. J.; Gagliardi, L.; Lu, C. C. J. Am. Chem. Soc. 2014, 136, 1842-1855. (c) Clouston, L. J.; Siedschlag, R. B.; Rudd, P. A.; Planas, N.; Hu, S.; Miller, A. D.; Gagliardi, L.; Lu, C. C. J. Am. Chem. Soc. 2013, 135, 13142-13148.

(20) For some neutral alkyl complexes with multiple Mo-Mo bonds see this reference and reference $46^{(\mathrm{b}-\mathrm{d})}$ : (a) Huq, F.; Mowat, W.; Shortland, A.; Skapski, A. C.; Wilkinson, G. J. Chem. Soc. D Chem. Commun. 1971, 1079-108o. (b) Girolami, G. S.; Mainz, V. V.; Andersen, R. A. J. Am. Chem. Soc. 1982, 104, 20412042. (c) Girolami, G. S.; Mainz, V. V.; Andersen, R. A. J. Am. Chem. Soc. 1981, 103, 3953-3955. (d) Cotton, F. A.; Wiesinger, K. J.; Girolami, G. S.; Mainz, V. V.; Andersen, R. A. Inorg. Chem. 1990, 29, 2594-2599.

(21) Cambridge Structural Database (Version 5.36). Allen, F. H.; Kennard, O. Chemical Design Automation News 1993, 8, 3137.

(22) (a) Williamson, D. H.; Wilkinson, G. J. Am. Chem. Soc. 1974, $96,3824-3828$. 
(23) McKeever, L. D.; Waack, R. J. Chem. Soc. D Chem. Commun. 1969, 750-751.

(24) (a) M. Brookhart, M. L. H. Green, G. Parkin, Proc. Natl. Acad. Sci. U. S. A. 2007, 104, 6908-6914. (b) Brookhart, M.; Green, M. L. H.; Wong, L.-L. Prog. Inorg. Chem. 1988, 36, 1-124. (c) Brookhart, M.; Green, M. L. H. J. Organomet. Chem. 1983, 250, 395-408.

(25) Green, J. C.; Green, M. L. H.; Parkin, G. Chem. Commun. 2012, 48, 11481-11503.

(26) (a) Kühnen, M.; Günther, H.; Amoureux, J.-P.; Fernandez, C. Magn. Reson. Chem. 2002, 40, 24-30. (b) Mahi, L.; Duplan, J. C.; Briguet, A. Magn. Reson. Chem. 1998, 36, 515-19. (c) See also pages 42-43 of reference 1c.

(27) (a) Bartholomew, E. R.; Bertz, S. H.; Cope, S.; Murphy, M.; Ogle, C. A. J. Am. Chem. Soc. 20o8, 130, 11244-11245. (b) Wang, L.-S.; Cowie, M. Organometallics 1995, 14, 3040-3057.

(28) (a) Morse, P. M.; Girolami, G. S. J. Am. Chem. Soc. 1989, 111, 4114-16. (b) Morris, R. J.; Girolami, G. S. Organometallics 1989, 8, 1478-1485. (c) Morris, R. J.; Girolami, G. S. Organometallics, 1988, 110, 6245-6246.

(29) (a) Fürstner, A.; Krause, H.; Lehmann, C. W. Angew. Chem., Int. Ed. Engl. 2oo6, 45, 440-444. (b) Fürstner, A.; Martin, R.; Krause, H.; Seidel, G.; Goddard, R.; Lehmann, C. W. J. Am. Chem. Soc. 2oo8, 130, 8773-8787.

(30) Chiu, M.; Hoyt, H. M.; Michael, F. E.; Bergman, R. G.; van Halbeek, H. Angew. Chem., Int. Ed. 2oo8, 47, 6073-6o66.

(31) (a) Pfennig, V.; Seppelt, K.; Robertson, N. Angew. Chem., Int. Ed. 1997, 36, 1350-1352. (b) Seidel, S.; Seppelt, K. Angew. Chemie Int. Ed. 200o, 39, 3923-3925.

(32) Cordero, B.; Gómez, V.; Platero-Prats, A. E.; Revés, M.; Echeverría, J.; Cremades, E.; Barragán, F.; Alvarez, S. Dalton Trans. 2008, 21, 2832-2838.

(33) (a) Hao, S.; Gambarotta, S.; Bensimon, C. J. Am. Chem. Soc. 1992, 114, 3556-3557. (b) Hao, S.; Song, J.-I.; Berno, P.; Gambarotta, S., Organometallics, 1994, 13, 1326-1335.

(34) Krausse, J.; Marx, G.; Schödl, G. J. Organomet. Chem. 1970, 21, 159-168.

(35) Campbell, R.; Carrella, L. M.; Clegg, W.; Mulvey, R. E.; Rentschler, E.; Robertson, S. D.; Russo, L. Inorg. Chem. 2011, 50, 4656-4659.

(36) Liu, S.-C.; Ke, W.-L.; Yu, J.-S. K.; Kuo, T.-S.; Tsai, Y.-C. Angew. Chem., Int. Ed. 2012, 51, 6394-6397.

(37) Al-Afyouni, M. H.; Fillman, K. L.; Brennessel, W. W.; Neidig, M. L. J. Am. Chem. Soc. 2014, 136, 15457-1546o.

(38) (a) Fischer, K.; Jonas, K.; Misbach, P.; Stabba, R.; Wilke, G. Angew. Chem., Int. Ed. 1973, 12, 943-953. (b) Jonas, K.; Pörschke, K. R.; Krüger, C.; Tsay, Y.-H. Angew. Chem., Int. Ed. 1976, 15, 621-622. (c) Pörschke, K.-R.; Jonas, K.; Wilke, G.; Benn, R.; Mynott, R.; Goddard, R.; Krüger, C. Chem. Ber. 1985, 118, 275-297. (d) Pörschke, K.-R.; Jonas, K.; Wilke, G. Chem. Ber. 1988, 121, 19131919. (e) Kaschube, W.; Pörschke, K.-R.; Angermund, K.; Krüger, C.; Wilke, G. Chem. Ber. 1988, 121, 1921-1929. (f) Wilke, G. Angew. Chem., Int. Ed. 1988, 27, 185-206.

(39) (a) Bolton, P. D.; Clot, E.; Cowley, A. R.; Mountford, P. J. Am. Chem. Soc. 2006, 128, 15005-15018. (b) Bryliakov, K. P.; Talsi, E. P.; Voskoboynikov, A. Z.; Lancaster, S. J.; Bochmann, M. Organometallics, 2008, 27, 6333-6342. (c) Weng, Z.; Teo, S.; Koh, L. L.; Hor, T. S. A. Chem. Soc. 20o6, 12, 1319-1321. (d) Ogoshi, S.; Ueta, M.; Arai, T.; Kurosawa, H. J. Am. Chem. Soc. 2005, 127, 12810-12811. (e) Hratchian, H. P.; Chowdhury, S. K.; GutiérrezGarcía, V. M.; Amarasinghe, K. K. D.; Heeg, M. J.; Schlegel, H. B.; Montgomery, J. Organometallics 2004, 23, 4336-4346.

(40) Braunstein, P.; Boag, N. M. Angew. Chem., Int. Ed. 2001, 40, 2427-2433.

(41) (a) Park, J. W.; Mackenzie, P. B.; Schaefer, W. P.; Grubbs, R. H. J. Am. Chem. Soc. 1986, 108, 6402-6404. (b) Ozawa, F.; Park, J. W.; Mackenzie, P. B.; Schaefer, W. P.; Henling, L. M.;
Grubbs, R. H. J. Am. Chem. Soc. 1989, 111, 1319-1327. (c) Mackenzie, P. B.; Coots, R. J.; Grubbs, R. H. Organometallics, 1989, 8, 814 .

(42) (a) Casey, C. P.; Fagan, P. J.; Miles, W. H. J. Am. Chem. Soc. 1982, 104, 1134-1136. (b) Bursten, B. E.; Cayton, R. H. Organometallics, 1986, 5, 1051-1053.

(43) (a) Stults, S. D.; Andersen, R. A.; Zalkin, A. J. Am. Chem. Soc. 1989, 111, 4507-4508. (b) Schwartz, D. J.; Ball, G. E.; Andersen, R. A. J. Am. Chem. Soc. 1995, 117, 6027-6040. (c) Dietrich, H. M.; Grove, H.; Tömroos, K. W.; Anwander, R. J. Am. Chem. Soc. 2006, 128, 1458-1459.

(44) (a) Niemeyer, M.; Power, P. P. Chem. Commun. 1996, 13, 1573-1574. (b) Chan, M. C. W.; Cole, J. M.; Gibson, V. C.; Howard, J. A. K. Chem. Commun. 1997, 24, 2345-2346.

(45) (a) Wigginton, J. R.; Trepanier, S. J.; McDonald, R.; Ferguson, M. J.; Cowie, M. Organometallics 2005, 24, 6194-6211. (b) Moret, M.-E.; Serra, D.; Bach, A.; Chen, P. Angew. Chem., Int. Ed. 2010, 49, 2873-2877.

(46) For bridging methyl groups in metal-metal bonded dimolybdenum complexes see: (a) Shin, J. H.; Parkin, G. Chem. Comm 1998, 1273-1274. (b) García, M. E.; Ramos, A.; Ruiz, M. A.; Lanfranchi, M.; Marchio, L. Organometallics, 2007, 26, 6197-6212. (c) Alvarez, M. A.; García-Vivó, D.; García, M. E.; Martínez, M. E.; Ramos, A.; Ruiz, M. A. Organometallics, 20o8, 27, 1973-1975. (d) Ma, J.-G.; Aksu, Y.; Gregoriades, L. J.; Sauer, J.; Driess, M. Dalton Trans. 2010, 39, 103-106.

(47) (a) Andersen, R. A.; Jones, R. A.; Wilkinson, G. J. Chem. Soc. Dalt. Trans. 1978, 5, 446-453. (b) Hursthouse, M. B.; Malik, K. M. A.; Sales, K. D. J. Chem. Soc. Dalt. Trans. 1978, 10, 1314-1318. (c) Morse, P. M.; Spencer, M. D.; Wilson, S. R.; Girolami, G. S. Organometallics, 1994, 13, 1646-1655.

(48) (a) Noh, S. K.; Sendlinger, S. C.; Janiak, C.; Theopold, K. H. J. Am. Chem. Soc. 1989, 111, 9127-9129. (b) Heintz, R. A.; Ostrander, R. L.; Rheingold, A. L.; Theopold, K. H. J. Am. Chem. Soc. 1994, 116, 11387-11396. (c) Kreisel, K. A.; Yap, G. P. A.; Theopold, K. H. Chem. Comm 2007, 15, 1510-1511.

(49) (a) Albahily, K.; Fomitcheva, V.; Shaikh, Y.; Sebastiao, E.; Gorelsky, S. I.; Gambarotta, S.; Korobkov, I.; Duchateau, R. Organometallics 2011, 30, 4201-4210. (b) Vidyaratne, I.; Nikiforov, G. B.; Gorelsky, S. I.; Gambarotta, S.; Duchateau, R.; Korobkov, I. Angew. Chem., Int. Ed. 2009, 48, 6552-6556. (c) Horvath, S.; Gorelsky, S. I.; Gambarotta, S.; Korobkov, I. Angew. Chem., Int. Ed. 2008, 47, 9937-9940.

(50) (a) Appleton, T. G.; Clark, H. C.; Manzer, L. E. Coord. Chem. Rev. 1973, 10, 335-422. (b) Hartley, F. R. Chem. Soc. Rev. 1973, 2, 163-179. (c) Manojlovic-Muir, L. J.; Muir, K. W. Inorg. Chim. Acta 1974, 10, 47-49. (d) Shustorovich, E. M.; PoraiKoshits, M. A.; Buslaev, Y. A. Coord. Chem. Rev. 1974, 17, 1-98. (e) Appleton, T. G.; Bennett, M. A. Inorg. Chem. 1978, 17, 738-747. (f) Purcell, K. I.; Kotz, J. C. Inorganic Chemistry, Saunders, W. B. Co. Philadelphia, 1977, Chapter 13. (g) Toledo, J. C.; Neto, B. d. S. L.; Franco, D. W. Coord. Chem. Rev. 2oo5, 249, 419-431. (h) Zhu, J.; Lin, Z.; Marder, T. B. Inorg. Chem. 2005, 44, 9384-9390. (i) Koller, S. G.; Martín-Romo, R.; Melero, J. S.; Colquhoun, V. P.; Schildbach, D.; Strohmann, C.; Villafañe, F. Organometallics 2014, 33, 7329-7332.

(51) Gaussian 09, Revisions A.o1 and D.o1; Frisch, M. J.; Trucks, G. W.; Schlegel, H. B.; Scuseria, G. E.; Robb, M. A.; Cheeseman, J. R.; Scalmani, G.; Barone, V.; Mennucci, B.; Petersson, G. A.; Nakatsuji, H.; Caricato, M.; Li, X.; Hratchian, H. P.; Izmaylov, A. F.; Bloino, J.; Zheng, G.; Sonnenberg, J. L.; Hada, M.; Ehara, M.; Toyota, K.; Fukuda, R.; Hasegawa, J.; Ishida, M.; Nakajima, T.; Honda, Y.; Kitao, O.; Nakai, H.; Vreven, T.; Montgomery Jr., J. A.; Peralta, J. E.; Ogliaro, F.; Bearpark, M. J.; Heyd, J.; Brothers, E. N.; Kudin, K. N.; Staroverov, V. N.; Kobayashi, R.; Normand, J.; Raghavachari, K.; Rendell, A. P.; Burant, J. C.; Iyengar, S. S.; Tomasi, J.; Cossi, M.; Rega, N.; Millam, N. J.; Klene, 
M.; Knox, J. E.; Cross, J. B.; Bakken, V.; Adamo, C.; Jaramillo, J.; Gomperts, R.; Stratmann, R. E.; Yazyev, O.; Austin, A. J.; Cammi, R.; Pomelli, C.; Ochterski, J. W.; Martin, R. L.; Morokuma, K.; Zakrzewski, V. G.; Voth, G. A.; Salvador, P.; Dannenberg, J. J.; Dapprich, S.; Daniels, A. D.; Farkas, Ö.; Foresman, J. B.; Ortiz, J. V.; Cioslowski, J.; Fox, D. J.; Gaussian, Inc.: Wallingford, CT, USA, 2009.

(52) Zhao, Y.; Truhlar, D. G. Theor. Chem. Acc. 2oo8, 120, 215241.

(53) Adamo, C.; Barone, V. J. Chem. Phys. 1999, 110, 6158-6170.

(54) Bader, R. F. W. Atom in Molecules: A Quantum Theory; Oxford University Press: Oxford, UK, 1995.

(55) Lu, T.; Chen, F.; Multiwfn: A Multifunctional Wavefunction Analyzer v. 3.3.7 J. Comput. Chem. 2012, 33, 580-592.

(56) Foroutan-Nejad, C.; Shahbazian, S.; Marek, R. Chem.Eur. J. 2014, 20, 10140-10152.

(57) Varadwaj, P. R.; Varadwaj, A.; Marques, H. M. J. Phys. Chem. A 2011, 115, 5592-5601.

(58) Varadwaj, P. R.; Cukrowski, I.; Marques, H. M. J. Phys. Chem. A 20o8, 112, 10657-10666.

(59) Poater, J.; Duran, M.; Solà, M.; Silvi, B. Chem. Rev. 2005, 105, 3911-3947.

(6o) Glendening, E. D.; Reed, A. E.; Carpenter, J. E.; Weinhold, F. NBO Version 3.o.

(61) Reed, A. E.; Curtiss, L. A.; Weinhold, F. Chem. Rev. 1988, $88,899-926$. 